\title{
A Biogenetically-Inspired Synthesis of a Ring-D Model of Kinamycin F: Insights into the Conformation of Ring-D
}

\author{
Supporting Information
}

Nan Chen, Marjolaine B. Carrière, Radoslaw S. Laufer, Nicholas J. Taylor ${ }^{\dagger}$ and Gary I. Dmitrienko*

Guelph-Waterloo Centre for Graduate Work in Chemistry and Biochemistry, $(G W C)^{2}$, Waterloo Campus, Department of Chemistry, University of Waterloo, Waterloo, Ontario N2L 3G1, Canada 
Table of contents

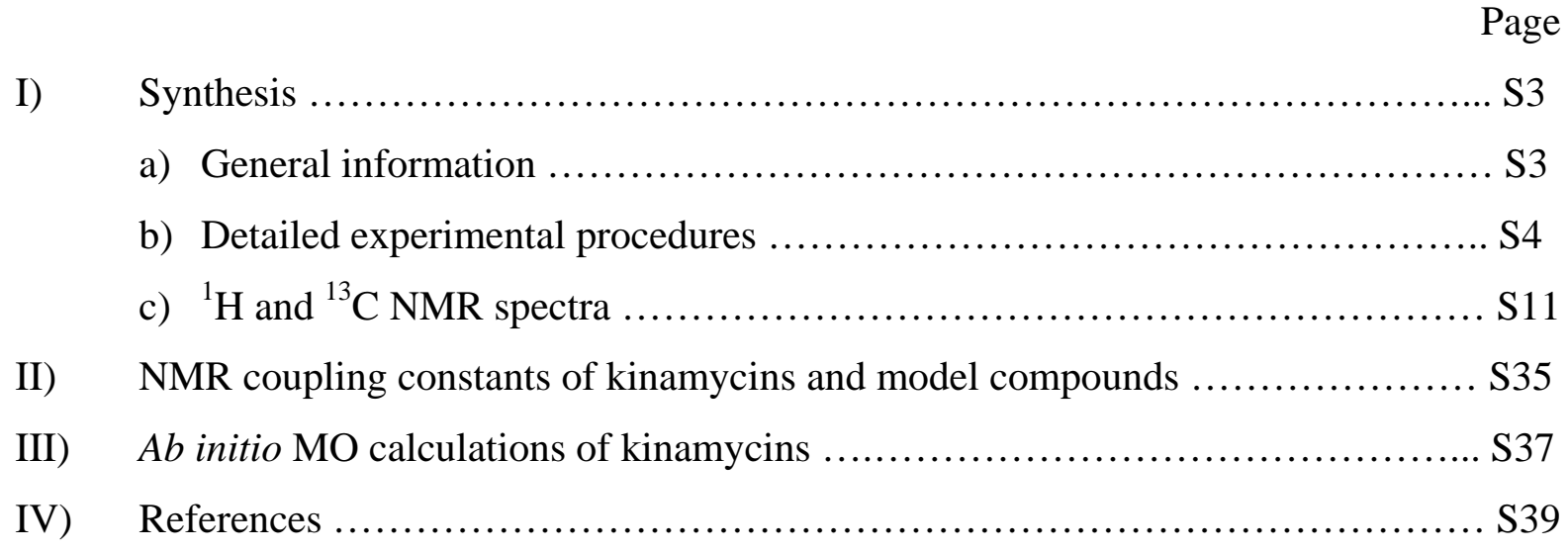




\section{I) Synthesis}

\section{a) General information}

Materials and Methods. All reactions were carried out in flame and oven-dried glassware under an argon or nitrogen atmosphere, unless otherwise specified. All solvents were reagent grade. Anhydrous tetrahydrofuran (THF) was freshly distilled from sodium/benzophenone under nitrogen prior to use. Deionized water was supplied by a Biolab vertical series reverse osmosis system. All commercial reagents were purchased from either Aldrich Chemical Co. or BDH Inc., and were used as received unless otherwise indicated. Reactions were magnetically stirred and monitored by thin layer chromatography (TLC) with Merck pre-coated silica gel plates (silica gel $60 \mathrm{~F}_{254}$ on aluminum sheet). Flash column chromatography was carried out using the Merck silica gel (70-230 mesh) or the SiliCycle silica gel (60 $\AA$ ). All reported yields refer to chromatograhpically and spectroscopically pure compounds, unless otherwise specified.

Characterization Methods. ${ }^{1} \mathrm{H}$ NMR spectra were recorded on a Brüker AVANCE500 (500 MHz), Brüker AVANCE300 (300 MHz), Brüker AC300 (300 MHz) and Brüker AC200 (200 $\mathrm{MHz}$ ) NMR spectrometer. ${ }^{13} \mathrm{C}$ NMR spectra were broad band decoupled and recorded on a Brüker AVANCE500 (125.8 MHz), Brüker AVANCE300 (75.5 MHz), Brüker AC300 (75.5 MHz) and Brüker AC200 (50 MHz) NMR spectrometer using the carbon signal of the deuterated solvent as the internal standard. HMQC, HMBC and difference NOE experiments were performed on the Brüker AVANCE500 spectrometer. The following abbreviations are used for NMR peak multiplicities: s, singlet; d, doublet; t, triplet; q, quartet; dd, doublet of doublets; dt, doublet of triplet; m, multiplet; br, broad; w, weak. Chemical shifts are reported in parts per million (ppm) relative to either TMS $(\delta 0.0)$, chloroform $(\delta 7.26)$, DMSO $(\delta 2.50)$ or acetone $(\delta$ 2.05) for ${ }^{1} \mathrm{H}$ NMR, and either chloroform ( $\delta$ 77.16), DMSO ( $\delta$ 39.52) or acetone $(\delta 29.84)$ for ${ }^{13} \mathrm{C}$ NMR. Infrared spectra (IR) were recorded on a Perkin-Elmer spectrum RX I FT-IR spectrometer as $\mathrm{KBr}$ discs or thin films on $\mathrm{NaCl}$ plate, as indicated in each individual case. High/low resolution electron impact (EI) and chemical ionization (CI) mass spectra (MS) were measured by the McMaster Regional Centre for Mass Spectrometry (Department of Chemistry, McMaster University, Hamilton, Ontario, Canada) and by the WATSPEC Mass Spectrometry Facility (Department of Chemistry, University of Waterloo, Waterloo, Ontario, Canada). 
Elemental/combustion analysis was performed by the M-H-W Laboratories (Phoenix, Arizona, USA). Melting points were determined on a MEL-TEMP melting point apparatus and were uncorrected.

\section{b) Detailed experimental procedures}<smiles>C[C@H]1O[C@@H]2C(=O)c3ccccc3C(=O)[C@@]21C</smiles>

2,3-Epoxy-3-methyl-1,4-naphthoquinone (11): The commercial 2-methyl-1,4-naphthoquinone 10 (98\%, $5.005 \mathrm{~g}, 28.5 \mathrm{mmol})$ was dissolved completely in ethanol $(20 \mathrm{~mL})$ upon heating the solution to about $70{ }^{\circ} \mathrm{C}$ under the air atmosphere. The solution was then cooled to about $50{ }^{\circ} \mathrm{C}$ and aqueous hydrogen peroxide solution $(30 \%, 10 \mathrm{~mL})$ was added dropwise during a period of $20 \mathrm{~min}$. Then aqueous sodium carbonate solution $\left(2.5 \mathrm{~g}\right.$ of $\mathrm{Na}_{2} \mathrm{CO}_{3}$ dissolved in $10 \mathrm{~mL}$ of deionized water) was added dropwise during a period of $15 \mathrm{~min}$ in order to avoid a rapid increase of the solution temperature. Large amount of gas bubbles were generated during the addition of $\mathrm{Na}_{2} \mathrm{CO}_{3}$ solution, and the yellow color of the quinone solution gradually disappeared. The almost colorless reaction solution was kept stirring for another 5 min after the addition of base, during which some white solid precipitated from the solution. Upon quenching the reaction with deionized water $(250 \mathrm{~mL})$, large amount of snow-white solid precipitated from the solution. The white solid was collected by vacuum filtration and washed thoroughly with $\mathrm{H}_{2} \mathrm{O}(25 \mathrm{~mL})$. The product was further dried overnight under vacuum to yield a fine white power (4.112 g, 21.9 mmol, 77\% yield) as the desired pure compound. IR (KBr) 1701, 1595, 1337, 1298, 1250, 1194 $\mathrm{cm}^{-1} ;{ }^{1} \mathrm{H}$ NMR (300 MHz, $\mathrm{CDCl}_{3}$ ) $\delta$ 8.05-7.89 (m, 2 H), 7.80-7.68 (m, $2 \mathrm{H}$ ), 3.85 (s, $1 \mathrm{H}$ ), 1.72 (s, $3 \mathrm{H}) ;{ }^{13} \mathrm{C}$ NMR $\left(75 \mathrm{MHz}, \mathrm{CDCl}_{3}\right) \delta 192.0,191.9,134.7,134.5,132.2,132.1,127.6,126.9$, 61.6, 61.5, 14.8; high resolution mass spectrum (EI) $\mathrm{m} / z$ $188.0470\left[\mathrm{M}^{+}\right.$; calculated for $\mathrm{C}_{11} \mathrm{H}_{8} \mathrm{O}_{3}$ : 188.0473]; Mp. $93.5-94.5^{\circ} \mathrm{C}$ (lit. ${ }^{1} 94.5-95.5{ }^{\circ} \mathrm{C}$ ). 
<smiles>C[C@H]1[C@@H](O)c2ccccc2[C@H](O)[C@@H]1O</smiles>

2,3-Epoxy-1,4-hydroxy-3-methyl-1,2,3,4-tetrahydronaphthalene (12): 2,3-Epoxy-3-methyl1,4-naphthoquinone 11 (0.376 g, $2.0 \mathrm{mmol}$ ) was dissolved in methanol (30 mL) and the solution was cooled to about $0{ }^{\circ} \mathrm{C}$ with an ice bath. Sodium borohydride $(0.0767 \mathrm{~g}, 2.0 \mathrm{mmol})$ was added to the solution in one portion under stirring and then the ice bath was removed. The solution was stirred for another $10 \mathrm{~min}$ and the temperature of the solution raised to $\mathrm{ca} .18^{\circ} \mathrm{C}$. The solvent was then removed in vacuo at room temperature and the remained white solid was mixed with saturated aqueous $\mathrm{NH}_{4} \mathrm{Cl}$ solution $(250 \mathrm{~mL})$. The obtained aqueous solution was extracted thoroughly with ethyl acetate $(6 \times 80 \mathrm{~mL})$, and the combined organic phase was dried over $\mathrm{Na}_{2} \mathrm{SO}_{4}$ and concentrated in vacuo. The epoxy diol 11 was obtained quantitatively as a white powder (0.388 g, 2.0 mmol, 100\% yield). IR (KBr) 3295, 1508, 1420, 1348, 1186, 1118, 1094, 1042, $1009 \mathrm{~cm}^{-1}$; ${ }^{1} \mathrm{H}$ NMR (200 MHz, DMSO-d6) $\delta$ 7.52-7.37 (m, $\left.2 \mathrm{H}\right)$, 7.30-7.18 (m, $\left.2 \mathrm{H}\right)$, 5.84-5.72 (m, 2 H), 4.80 (d, $J=7.0 \mathrm{~Hz}, 1 \mathrm{H}$ ), 4.65 (d, $J=8.5 \mathrm{~Hz}, 1 \mathrm{H}), 3.33$ (d, $J=1.5 \mathrm{~Hz}, 1 \mathrm{H}$ ), 1.47 (s, $3 \mathrm{H}$ ); ${ }^{13} \mathrm{C}$ NMR (50 MHz, DMSO-d6/D $\left.\mathrm{D}_{2} \mathrm{O}\right) \delta$ 136.5, 135.7, 126.89, 126.85, 125.5, 125.4, 68.7, 65.8, 61.9, 59.4, 19.2; high resolution mass spectrum (EI) $\mathrm{m} / \mathrm{z} 192.0789$ [M $\mathrm{M}^{+}$; calculated for $\mathrm{C}_{11} \mathrm{H}_{12} \mathrm{O}_{3}$ : 192.0786]; Mp. 148-153 ${ }^{\circ} \mathrm{C}$ (decomp.).<smiles>CC(C)OC(=O)C(C)[C@@]1(C)O[C@@H]2[C@@H](OC(=O)C(C)C)c3ccccc3[C@@H]21</smiles>

2,3-Epoxy-1,4-hydroxy-3-methyl-1,2,3,4-tetrahydronaphthalene Diisobutylryl ester (13): The epoxy diol 12 (0.385 g, $2.0 \mathrm{mmol})$ was mixed with catalytic amount of 4dimethylaminopyridine (DMAP, $0.0506 \mathrm{~g}, 0.41 \mathrm{mmol}$ ), followed by the addition of pyridine (20 $\mathrm{mL})$. Then the commercial isobutylryl chloride $(98 \%, 0.86 \mathrm{~mL}, 8.0 \mathrm{mmol}$ ) was added dropwise through a syringe during a period of $0.5 \mathrm{~min}$ to the above reaction mixture, and the resulting 
solution was stirred under the air atmosphere for $24 \mathrm{~h}$ at ambient temperature. The reaction was quenched by dilution with $\mathrm{H}_{2} \mathrm{O}(20 \mathrm{~mL})$ and the obtained solution was further stirred for $15 \mathrm{~min}$, during which large amount of white precipitate formed. The white precipitate was filtered and washed with $\mathrm{H}_{2} \mathrm{O}(20 \mathrm{~mL})$ and it was then re-dissolved in $\mathrm{CH}_{2} \mathrm{Cl}_{2}(50 \mathrm{~mL})$. The $\mathrm{CH}_{2} \mathrm{Cl}_{2}$ solution was washed with saturated aqueous $\mathrm{CuSO}_{4}$ solution $(1 \times 50 \mathrm{~mL})$ and $\mathrm{H}_{2} \mathrm{O}(1 \times 50 \mathrm{~mL})$. The organic solution was dried over $\mathrm{Na}_{2} \mathrm{SO}_{4}$ and the solvent was removed in vacuo, yielding a snowwhite solid as the pure product (0.426 g, $1.27 \mathrm{mmol}$, 64\% yield). IR (KBr) 2980, 2933, 1735, 1496, 1448, 1437, 1388, 1355, 1187, 1146, $1103 \mathrm{~cm}^{-1} ;{ }^{1} \mathrm{H}$ NMR (300 MHz, $\left.\mathrm{CDCl}_{3}\right) \delta$ 7.40-6.80 (m, 4 H), 6.23 (s, 1 H), 6.13 (s, 1 H), 3.48 (s, 1H), 2.74 (s, very br, 2 H), 1.40 (s, 3 H), 1.26 (s, 12 $\mathrm{H}) ;{ }^{13} \mathrm{C} \mathrm{NMR}\left(75 \mathrm{MHz}, \mathrm{CDCl}_{3}\right) \delta 177.1,177.0,131.4,130.4,128.19,128.12,125.7,125.5,70.3$, 68.3, 58.5, 57.6, 34.3, 19.26, 19.20, 18.99, 18.78; low resolution mass spectrum (CI) $\mathrm{m} / \mathrm{z} 350.2$ $\left[\left(\mathrm{M}+\mathrm{NH}_{4}\right)^{+}\right]$; Mp. $120-120.5^{\circ} \mathrm{C}$. All attempts to crystallize 13 in various pure solvents $\left(\mathrm{Et}_{2} \mathrm{O}\right.$, EtOAc, acetone, benzene, THF and $\mathrm{CDCl}_{3}$ ) yielded good quality single crystals suitable for Xray diffraction crystallography studies, and the corresponding ORTEP plot of the single crystal is already shown in the manuscript. See the submitted CIF file for full crystallographic data.<smiles>CC(=O)O[C@H]1[C@@H](O)c2ccccc2[C@H](O)[C@@]1(C)O</smiles><smiles>CC(=O)O[C@H]1c2ccccc2[C@@H](O)[C@@](C)(O)[C@@H]1O</smiles>

Triol acetates (14): The epoxy diol 12 (0.963 g, $5.00 \mathrm{mmol})$ was mixed with NaOAc (99\%, $2.072 \mathrm{~g}, 25.0 \mathrm{mmol})$ and the commercial $\mathrm{Me}_{4} \mathrm{NBH}(\mathrm{OAc})_{3}(95 \%, 1.525 \mathrm{~g}, 5.50 \mathrm{mmol})$ in a flameand oven-dried round bottom flask, followed by addition of anhydrous THF (50 mL). Large amount of gas bubbles were generated at the beginning and the reaction mixture was heated to reflux in an oil bath for $6 \mathrm{~h}$ under argon atmosphere. The reaction mixture was further stirred for $1 \mathrm{~h}$ without heating until the solution cooled gradually to room temperature. The reaction was quenched by the addition of saturated aqueous $\mathrm{NaHCO}_{3}$ solution $(50 \mathrm{~mL})$ and the mixture was further stirred for $10 \mathrm{~min}$. Another $50 \mathrm{~mL}$ of $\mathrm{H}_{2} \mathrm{O}$ was added to completely dissolve the remained $\mathrm{NaOAc}$ powder. The aqueous solution was then extracted thoroughly with $\mathrm{CH}_{2} \mathrm{Cl}_{2}(8 \times 100 \mathrm{~mL})$ and the organic phase was dried over $\mathrm{Na}_{2} \mathrm{SO}_{4}$ and concentrated in vacuo. The crude epoxide ring-opening product was obtained as a slightly yellow foamy solid (0.809 g). Some more crude 
product was successfully recovered from the aqueous phase in the previous extraction step: the aqueous phase was concentrated to dryness and the remaining solid residue was stirred with $2 \mathrm{~L}$ of $\mathrm{CH}_{2} \mathrm{Cl}_{2}$ for a while, and the $\mathrm{CH}_{2} \mathrm{Cl}_{2}$ solution was then dried over $\mathrm{Na}_{2} \mathrm{SO}_{4}$, leading to another $0.180 \mathrm{~g}$ of the crude product upon removal of the solvent. The combined crude product $(0.989 \mathrm{~g})$ was further purified by charcoal decolorization in $\mathrm{CH}_{2} \mathrm{Cl}_{2}$ and some off-white foamy solid (0.956 g, 3.79 mmol, 76\% yield) was obtained as the final pure product, which is consist of two regioisomers of the triol acetates $14 \mathrm{~A}$ and $\mathbf{1 4 B}$ in an approximate ratio of 1:1, as determined by NMR. This "pure" mixture is directly suitable for the next Zemplen deacylation and peracetylation reaction. It shall be pointed out that this epoxide ring-opening reaction can also be carried out quite smoothly in the absence of $\mathrm{NaOAc}$ as the external nucleophile, although such modification would lead to a slightly lower yield (ca. 50-60\%).

If pure form of each of the regioisomers is desired, flash column chromatography using a mixture of EtOAc and Hexane (3:1, v/v) as the eluent could be performed directly with the crude product, without the need of charcoal decolorization. The separated two pure triol acetates were then subjected to extensive NMR spectroscopy studies $\left({ }^{1} \mathrm{H},{ }^{13} \mathrm{C}\right.$, difference NOE, HMBC and HMQC).

Mixture ( 1:1) of 14A and 14B: IR (KBr) 3423, 1736, 1720, 1376, 1255, 1096, $1025 \mathrm{~cm}^{-1}$; IR (film) 3396, 2936, 1716, 1491, 1456, 1374, 1252, 1097, $1024 \mathrm{~cm}^{-1}$.

Regioisomer 14A: IR (film) 3392, 1719, 1375, 1251, 1094, $1037 \mathrm{~cm}^{-1}$; ${ }^{1} \mathrm{H}$ NMR (300 MHz, acetone-d6) $\delta 7.57$ (d, $J=7.8 \mathrm{~Hz}, 1 \mathrm{H}$ ), 7.50-7.20 (m, $3 \mathrm{H}$ ), 5.45 (d, $J=7.5 \mathrm{~Hz}, 1 \mathrm{H}$ ), 4.72 (d, $J=$ $6.3 \mathrm{~Hz}, 1 \mathrm{H}$ ), 4.70-4.55 (m, 2 H), 4.47 (d, $J=4.4$ Hz, 1 H), 3.78 (s, 1 H), 2.08 (s, 3H), 1.11 (s, 3 $\mathrm{H}) ;{ }^{1} \mathrm{H}$ NMR (500 MHz, acetone-d6/ $\left.\mathrm{D}_{2} \mathrm{O}\right) \delta 7.56(\mathrm{~d}, J=8.0 \mathrm{~Hz}, 1 \mathrm{H}), 7.40(\mathrm{~d}, J=7.0 \mathrm{~Hz}, 1 \mathrm{H})$, 7.36-7.27 (m, 2 H), 5.44 (d, $J=8.0$ Hz, 1 H), 4.56 (d, $J=7.5$ Hz, 1 H), 4.46 (s, 1 H), 2.08 (s, 3 H), 1.11 (s, $3 \mathrm{H}$ ); ${ }^{13} \mathrm{C}$ NMR (125 MHz, acetone-d6/D $\left.2 \mathrm{O}\right) \delta 171.4$, 138.1, 137.0, 130.5, 128.86, 128.85, 128.5, 77.7, 76.0, 73.1, 71.1, 21.2, 19.6; high resolution mass spectrum (EI) $\mathrm{m} / \mathrm{z}$ 235.0956 [(M-OH) ${ }^{+}$; calculated for $\mathrm{C}_{13} \mathrm{H}_{15} \mathrm{O}_{4}$ : 235.0970]; high resolution mass spectrum (CI) $\mathrm{m} / \mathrm{z}$ $235.0989\left[(\mathrm{M}-\mathrm{OH})^{+}\right.$; calculated for $\left.\mathrm{C}_{13} \mathrm{H}_{15} \mathrm{O}_{4}: 235.0970\right]$, $252.1258\left[\left(\mathrm{M}+\mathrm{NH}_{4}-\mathrm{H}_{2} \mathrm{O}\right)^{+}\right.$; calculated for $\mathrm{C}_{13} \mathrm{H}_{18} \mathrm{NO}_{4}$ : 252.1236], 253.1130 [(M+H) ${ }^{+}$; calculated for $\mathrm{C}_{13} \mathrm{H}_{17} \mathrm{O}_{5}$ : 253.1076]; Mp. 153-155 ${ }^{\circ} \mathrm{C}$; Elemental/combustion analysis ${ }^{2}$ : calculated for $\mathrm{C}_{13} \mathrm{H}_{16} \mathrm{O}_{5}$ : C 61.90, H 6.39; found: C 61.89, H 6.48 . 
Regioisomer 14B: IR (film) 3415, 2926, 1725, 1644, 1493, 1457, 1374, 1246, 1099, $1027 \mathrm{~cm}^{-1}$; ${ }^{1} \mathrm{H}$ NMR (300 MHz, acetone-d6) $\delta$ 7.50-7.10 (m, $4 \mathrm{H}$ ), 5.89 (d, $\left.J=8.1 \mathrm{~Hz}, 1 \mathrm{H}\right), 4.49$ (s, $1 \mathrm{H}$ ), 4.38 (d, $J=4.5 \mathrm{~Hz}, 1 \mathrm{H}$ ), 4.30-4.15 (m, $1 \mathrm{H}), 3.91$ (s, $1 \mathrm{H}), 2.14$ (s, $3 \mathrm{H}), 1.11$ (s, $3 \mathrm{H}$ ); ${ }^{1} \mathrm{H}$ NMR (500 MHz, acetone-d6/ $\mathrm{D}_{2} \mathrm{O}$ ) $\delta$ 7.43-7.38 (m, $1 \mathrm{H}$ ), 7.34-7.28 (m, $2 \mathrm{H}$ ), 7.19-7.14 (m, $1 \mathrm{H}$ ), 5.88 (d, $J=8.5 \mathrm{~Hz}, 1 \mathrm{H}$ ), 4.49 (s, $1 \mathrm{H}$ ), 4.20 (d, $J=8.5 \mathrm{~Hz}, 1 \mathrm{H}$ ), 2.14 (s, $3 \mathrm{H}), 1.10$ (s, $3 \mathrm{H}$ ); ${ }^{13} \mathrm{C}$ NMR (125 MHz, acetone-d6/ $\left.\mathrm{D}_{2} \mathrm{O}\right) \delta$ 171.8, 137.9, 134.9, 131.3, 129.0, 128.9, 128.0, 76.0, 75.1, 73.6, 73.0, 21.2, 18.7; high resolution mass spectrum (EI) $\mathrm{m} / \mathrm{z} 234.0895\left[\left(\mathrm{M}-\mathrm{H}_{2} \mathrm{O}\right)^{+}\right.$; calculated for $\mathrm{C}_{13} \mathrm{H}_{14} \mathrm{O}_{4}$ : 234.0892]; high resolution mass spectrum (CI) m/z 235.1003 [(M-OH) ${ }^{+}$; calculated for $\mathrm{C}_{13} \mathrm{H}_{15} \mathrm{O}_{4}$ : 235.0970], $252.1256\left[\left(\mathrm{M}+\mathrm{NH}_{4}-\mathrm{H}_{2} \mathrm{O}\right)^{+}\right.$; calculated for $\mathrm{C}_{13} \mathrm{H}_{18} \mathrm{NO}_{4}$ : 252.1236], $253.1064\left[(\mathrm{M}+\mathrm{H})^{+}\right.$; calculated for $\left.\mathrm{C}_{13} \mathrm{H}_{17} \mathrm{O}_{5}: 253.1076\right]$; Mp. $45-48{ }^{\circ} \mathrm{C}$.

Difference NOE studies of compound $14 \mathrm{~A}$ and $14 \mathrm{~B}$ in acetone-d6/ $\mathrm{D}_{2} \mathrm{O}$ :

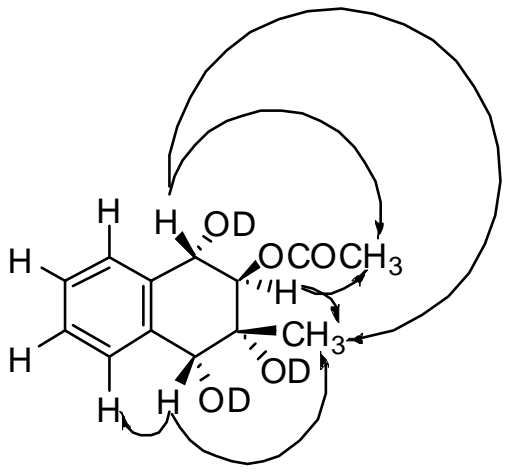

14A

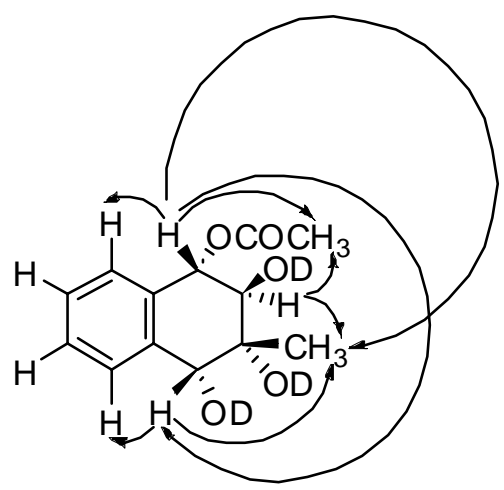

14B<smiles>CC1(O)C(O)C(O)c2ccccc2[C@@H]1O</smiles>

\section{Tetrol (15):}

A fresh $\mathrm{MeOH}$ solution of NaOMe $(1 \mathrm{M})$ was prepared by completely dissolving sodium metal (0.23 g, $10 \mathrm{mmol})$ in small amount of methanol $(\sim 4 \mathrm{~mL})$ first, and the final volume of this $\mathrm{NaOMe} / \mathrm{MeOH}$ solution was adjusted to $10.0 \mathrm{~mL}$ in a volumetric flask. A mixture ( 1:1) of the 
two triol acetates 14A and 14B (0.470 g, $1.86 \mathrm{mmol})$ was dissolved in methanol (18.8 $\mathrm{mL})$. The previously prepared $1 \mathrm{M} \mathrm{NaOMe} / \mathrm{MeOH}$ solution $(5.0 \mathrm{~mL}, 5 \mathrm{mmol})$ was added dropwise to the reaction mixture and the solution was stirred at room temperature for $1 \mathrm{~h}$ under the air atmosphere. The reaction was quenched by the addition of about $10 \mathrm{~g}$ of a weak acidic ion $\left(\mathrm{H}^{+}\right)$ exchange resin (CGC-271, 200-400 mesh, total exchange capacity 9.6\%meq/g). The mixture was stirred for 5 min until the $\mathrm{pH}$ of the solution reached around 6, as indicated by wet $\mathrm{pH}$ paper. Vacuum filtration gave a light yellow filtrate and the ion exchange resin was further washed with $\mathrm{MeOH}(100 \mathrm{~mL})$. The combined $\mathrm{MeOH}$ filtrate yielded a white (slightly yellow) foamy solid upon concentration in vacuo, which was then subjected to a charcoal decolorization in acetone. The obtained almost colorless acetone solution of the product gave a white foamy solid (0.385 g, $1.83 \mathrm{mmol}$, 98\% yield) upon removal of the solvent, which was proven by NMR spectroscopy to be the desired tetrol 15 (slightly hydrophilic and it shall be stored in a dessicator). IR (film) 3390, 2925, 2855, 1645, 1458, 1378, 1262, 1099, $1024 \mathrm{~cm}^{-1}$; ${ }^{1} \mathrm{H}$ NMR (300 MHz, DMSO-d6) $\delta$ 7.44 (d, $J=6.9 \mathrm{~Hz}, 1 \mathrm{H}), 7.36-7.20$ (m, $3 \mathrm{H}), 5.28$ (d, $J=6.6 \mathrm{~Hz}, 1 \mathrm{H}), 5.00$ (d, $J=5.1 \mathrm{~Hz}, 1 \mathrm{H})$, 4.87 (s, $1 \mathrm{H}), 4.41$ (s, $1 \mathrm{H}), 4.29$ (d, $J=3.9 \mathrm{~Hz}, 1 \mathrm{H}), 4.21$ (t, $J=6.3 \mathrm{~Hz}, 1 \mathrm{H}), 3.77$ (d, $J=6.6$ Hz, $1 \mathrm{H}), 1.00$ (s, $3 \mathrm{H}) ;{ }^{13} \mathrm{C}$ NMR (75 MHz, DMSO-d6) $\delta$ 138.2, 137.1, 129.0, 128.0, 127.3, 127.0, 74.4, 74.0, 72.7, 72.0, 20.1; high resolution mass spectrum (EI) m/z 192.0781 [(M- $\left.\mathrm{H}_{2} \mathrm{O}\right)^{+}$; calculated for $\mathrm{C}_{11} \mathrm{H}_{12} \mathrm{O}_{3}$ : 192.0786], 174.0674 [(M-2 $\left.\mathrm{H}_{2} \mathrm{O}\right)^{+}$; calculated for $\mathrm{C}_{11} \mathrm{H}_{10} \mathrm{O}_{2}$ : 174.0681]; high resolution mass spectrum (CI) $\mathrm{m} / \mathrm{z} 210.1122\left[\left(\mathrm{M}+\mathrm{NH}_{4}-\mathrm{H}_{2} \mathrm{O}\right)^{+}\right.$; calculated for $\mathrm{C}_{11} \mathrm{H}_{16} \mathrm{NO}_{3}$ : 210.1130], 228.1214 [(M+NH$)^{+}$; calculated for $\mathrm{C}_{11} \mathrm{H}_{18} \mathrm{NO}_{4}$ : 228.1236].

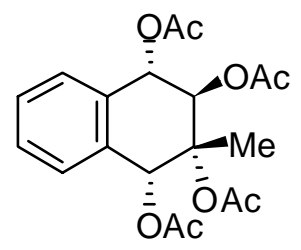

Tetra-acetate (16): The tetrol $15(0.053 \mathrm{~g}, 0.25 \mathrm{mmol})$ and $N, N$-dimethylaminopyridine (DMAP, 99\%, $0.307 \mathrm{~g}, 2.5 \mathrm{mmol}$ ) were dissolved in $\mathrm{CH}_{2} \mathrm{Cl}_{2}(5 \mathrm{~mL})$, resulting in a faint redbrown solution. Acetic anhydride (99.4\%, $0.24 \mathrm{~mL}, 2.5 \mathrm{mmol}$ ) was added dropwise during a period of $3 \mathrm{~min}$ at room temperature under stirring, which caused the faint red-brown color of the solution immediately turned to light yellow. The yellow reaction mixture was then stirred for 12 $\mathrm{h}$ at room temperature under air atmosphere. $\mathrm{MeOH}(10 \mathrm{~mL})$ was then added and the reaction 
mixture was further stirred for 20 min to quench the excess acetic anhydride. Upon removal of the solvent, some yellow-orange solid was obtained and it was then mixed with dilute $\mathrm{HCl}$ ( $2 \mathrm{M}$, $30 \mathrm{~mL})$, followed by extraction with $\mathrm{Et}_{2} \mathrm{O}(3 \times 50 \mathrm{~mL})$. The obtained light yellow organic phase was dried over $\mathrm{Na}_{2} \mathrm{SO}_{4}$ and concentrated in vacuo. A white (slightly yellow) foamy solid was obtained as the crude product $(0.085 \mathrm{~g})$ and the yellow color of the crude product was completely removed by charcoal decolorization in $\mathrm{Et}_{2} \mathrm{O}$. The pure product was obtained as a snow-white foamy solid (0.080 g, $0.21 \mathrm{mmol}$, 83\% yield). IR (film) 3474, 2992, 2939, 1750, 1374, 1256, 1227 1043, 1023 cm $^{-1}$; ${ }^{1} \mathrm{H}$ NMR (300 MHz, DMSO-d6) $\delta$ 7.47-7.24 (m, 4 H), 6.48 (s, 1 H), 5.96 (d, $J=6.0 \mathrm{~Hz}, 1 \mathrm{H}$ ), 5.85 (d, $J=6.0 \mathrm{~Hz}, 1 \mathrm{H}$ ), 2.13 (s, 3 H), 2.10 (s, 3 H), 2.08 (s, 3 H), 1.93 (s, 3 H), 1.50 (s, $3 \mathrm{H}$ ); ${ }^{1} \mathrm{H}$ NMR (300 MHz, $\left.\mathrm{CDCl}_{3}\right) \delta$ 7.55-7.50 (m, $1 \mathrm{H}$ ), 7.42-7.35 (m, $\left.2 \mathrm{H}\right)$, 7.237.20 (m, $1 \mathrm{H}), 6.78$ (s, $1 \mathrm{H}), 6.14$ (d, $J=7.2 \mathrm{~Hz}, 1 \mathrm{H}), 5.94$ (d, $J=7.2 \mathrm{~Hz}, 1 \mathrm{H}), 2.16$ (s, $3 \mathrm{H}$ ), 2.14 (s, $3 \mathrm{H}), 2.10$ (s, $3 \mathrm{H}$ ), 1.99 (s, $3 \mathrm{H}), 1.58$ (s, $3 \mathrm{H}) ;{ }^{13} \mathrm{C}$ NMR $\left(75 \mathrm{MHz}, \mathrm{CDCl}_{3}\right) \delta$ 171.0, 170.1, 169.9, 169.7, 132.9, 132.7, 130.7, 129.8, 129.4, 128.7, 128.1, 80.5, 72.7, 72.6, 71.5, 22.0, 21.2, 21.1, 16.4; high resolution mass spectrum (EI) $\mathrm{m} / \mathrm{z} 319.1180\left[(\mathrm{M}-\mathrm{OAc})^{+}\right.$; calculated for $\mathrm{C}_{17} \mathrm{H}_{19} \mathrm{O}_{6}$ : 319.1182].

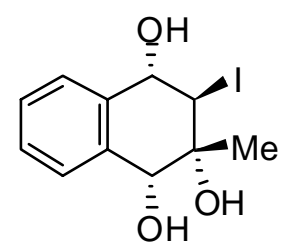

Iodohydrin (17): The epoxy diol 12 (0.096 g, 0.5 mmol), $\mathrm{Me}_{4} \mathrm{NBH}(\mathrm{OAc})_{3}(95 \%, 0.15 \mathrm{~g}, 0.55$ mmol) and sodium iodide (98\%, $0.383 \mathrm{~g}, 2.5 \mathrm{mmol}$ ) were mixed and dissolved in anhydrous THF ( $5 \mathrm{~mL}$ ). The reaction solution was heated to reflux in an oil bath for $6 \mathrm{~h}$ under argon atmosphere. Large amount of gas bubbles were generated at the beginning and the color of the solution turned from clear (beginning) to yellow (end). The reaction mixture was further stirred for $1 \mathrm{~h}$ without heating until it cooled gradually to the ambient temperature, followed by the addition of saturated aqueous $\mathrm{NaHCO}_{3}$ solution $(10 \mathrm{~mL})$ and further stirring of 10 min to quench the reaction. The solution was then stirred with $10 \%$ aqueous $\mathrm{Na}_{2} \mathrm{~S}_{2} \mathrm{O}_{3}$ solution $(10 \mathrm{~mL})$ for 5 min. After thorough extraction with $\mathrm{CH}_{2} \mathrm{Cl}_{2}(6 \times 25 \mathrm{~mL})$, the obtained organic phase was dried over $\mathrm{Na}_{2} \mathrm{SO}_{4}$ and concentrated in vacuo. A red shiny flake was obtained as the pure product (0.145 g, $0.45 \mathrm{mmol}, 90 \%$ yield). IR (KBr) 3400, $1017 \mathrm{~cm}^{-1}$; ${ }^{1} \mathrm{H}$ NMR (500 MHz, acetone-d6) $\delta$ 
7.59 (d, $J=7.5$ Hz, 1 H), 7.41-7.29 (m, 3 H), 4.97 (d, $J=8.0$ Hz, 1 H), 4.84-4.79 (m, 1 H), 4.75 (d, $J=9.0 \mathrm{~Hz}, 1 \mathrm{H}), 4.67$ (d, $J=5.5 \mathrm{~Hz}, 1 \mathrm{H}), 4.61$ (d, $J=5.0 \mathrm{~Hz}, 1 \mathrm{H}), 4.24$ (s, $1 \mathrm{H}), 1.20$ (s, 3 H); ${ }^{13} \mathrm{C}$ NMR (125 MHz, acetone-d6) $\delta$ 130.8, 129.1, 128.9, 128.7, 75.9, 75.8, 74.6, 74.5, 50.6, 23.4; high resolution mass spectrum (CI) $\mathrm{m} / \mathrm{z} 320.0169\left[\left(\mathrm{M}+\mathrm{NH}_{4}-\mathrm{H}_{2} \mathrm{O}\right)^{+}\right.$; calculated for $\mathrm{C}_{11} \mathrm{H}_{15} \mathrm{NO}_{2} \mathrm{I}$ : 320.0148], 338.0301 [( $\left.\mathrm{M}+\mathrm{NH}_{4}\right)^{+}$; calculated for $\mathrm{C}_{11} \mathrm{H}_{17} \mathrm{NO}_{3} \mathrm{I}$ : 338.0253].

\section{c) ${ }^{1} \mathrm{H}$ and ${ }^{13} \mathrm{C}$ NMR spectra}




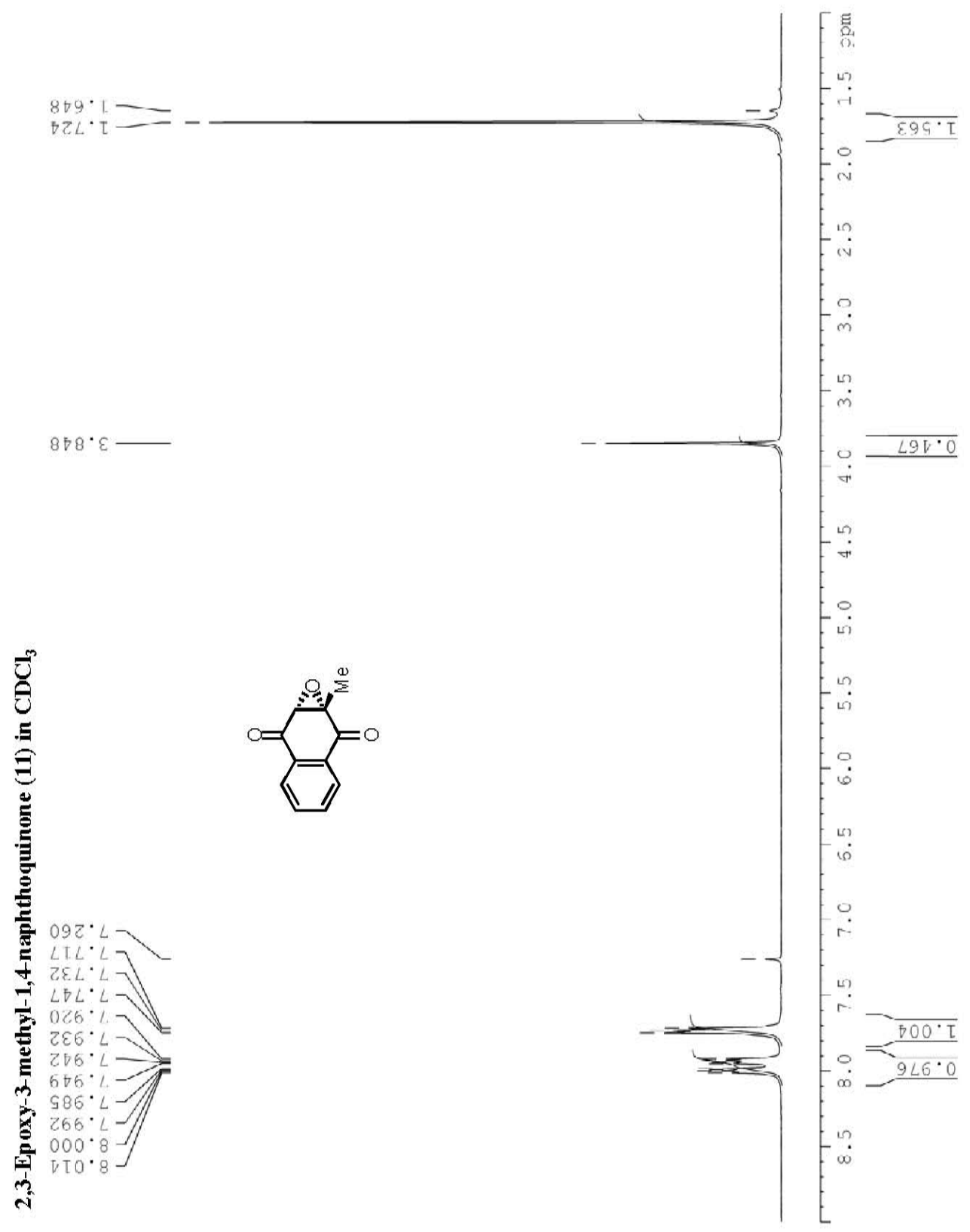




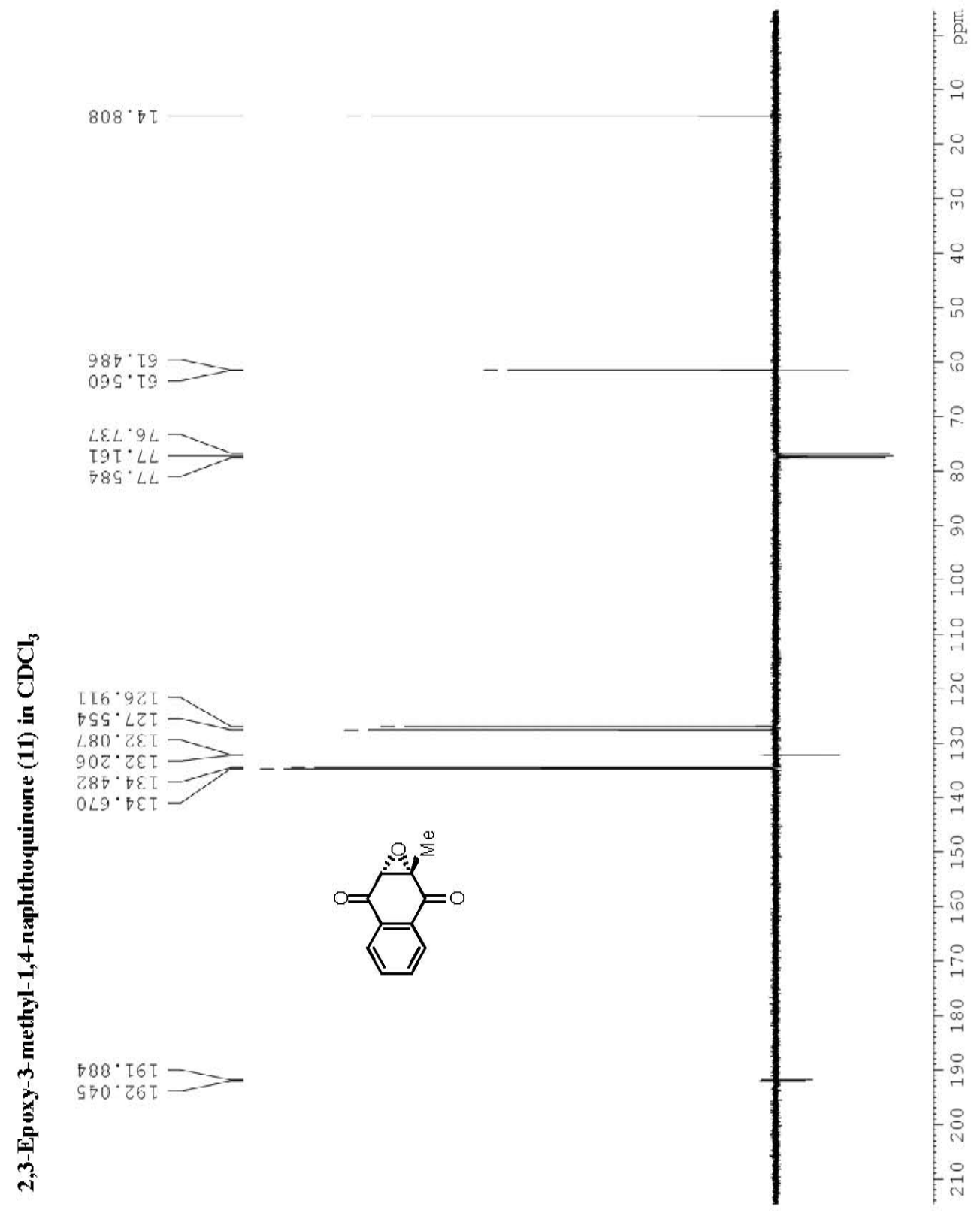




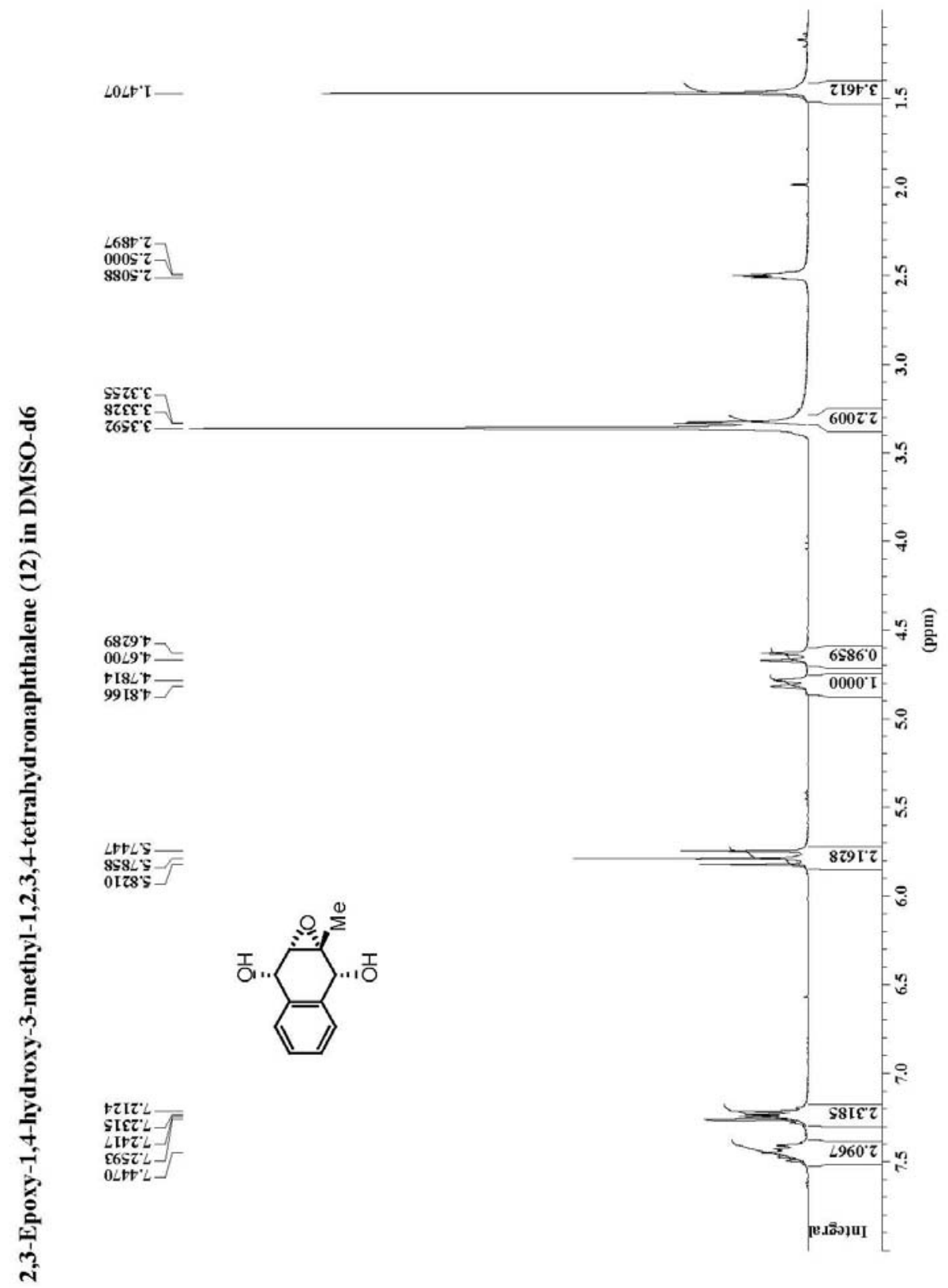




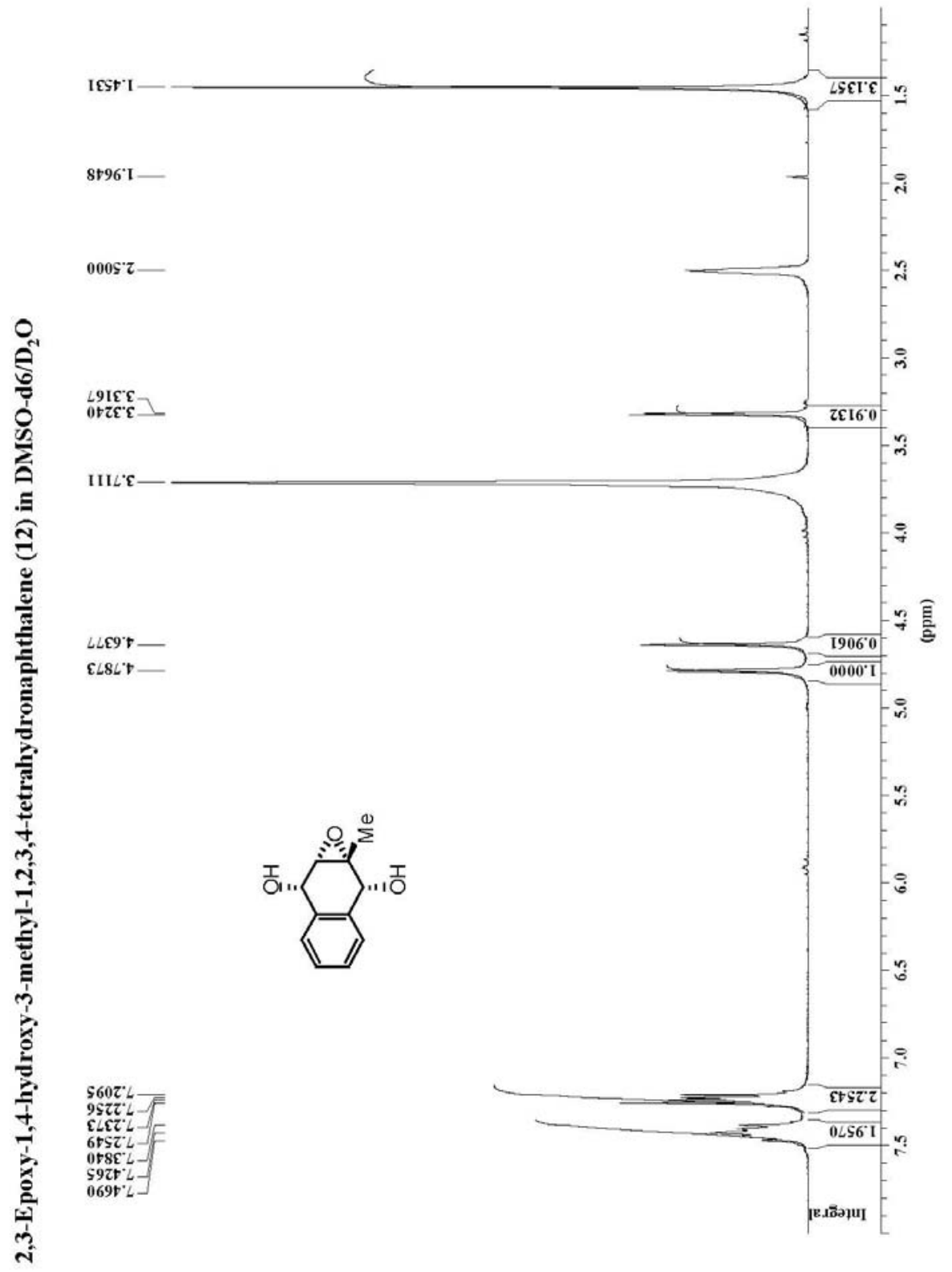




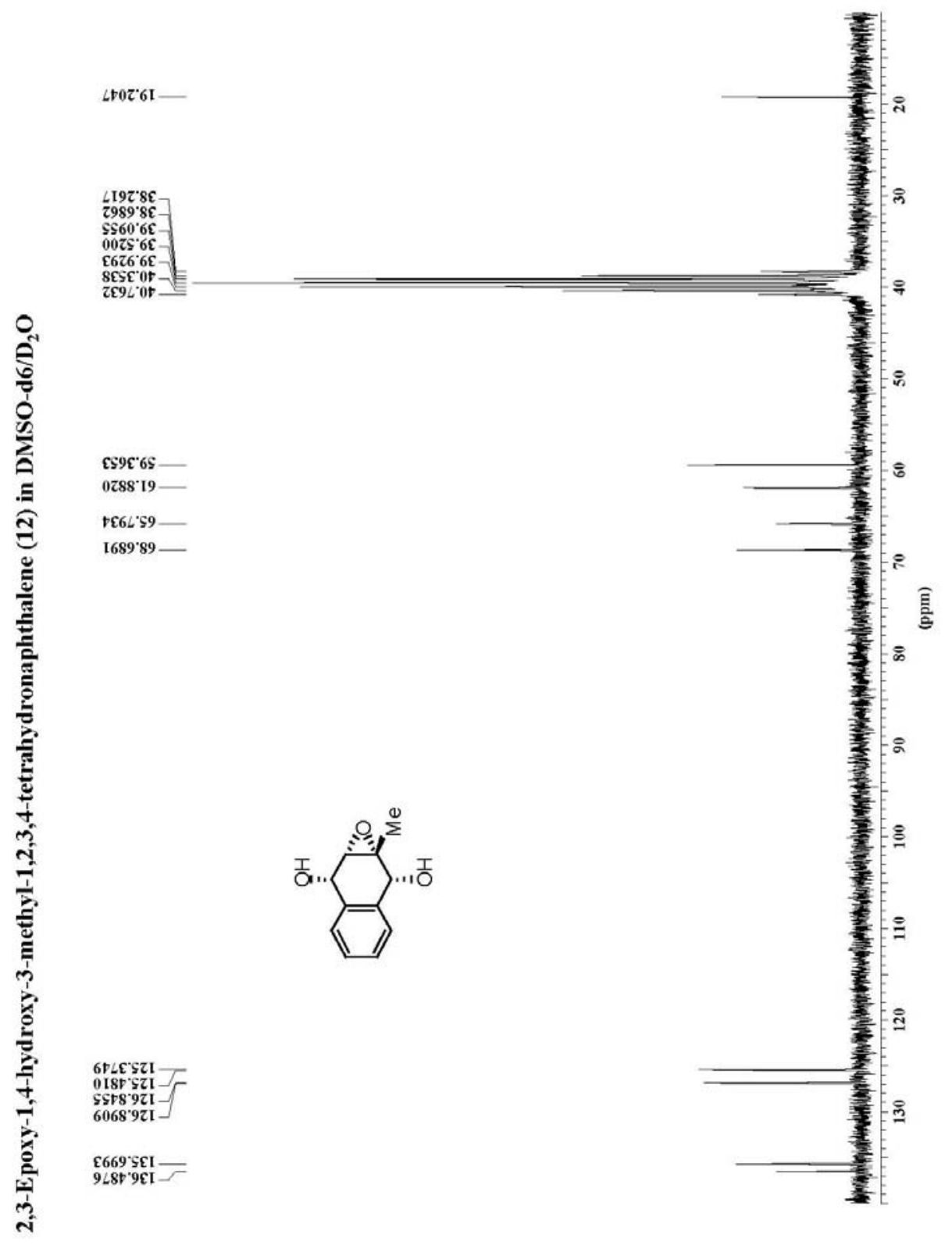




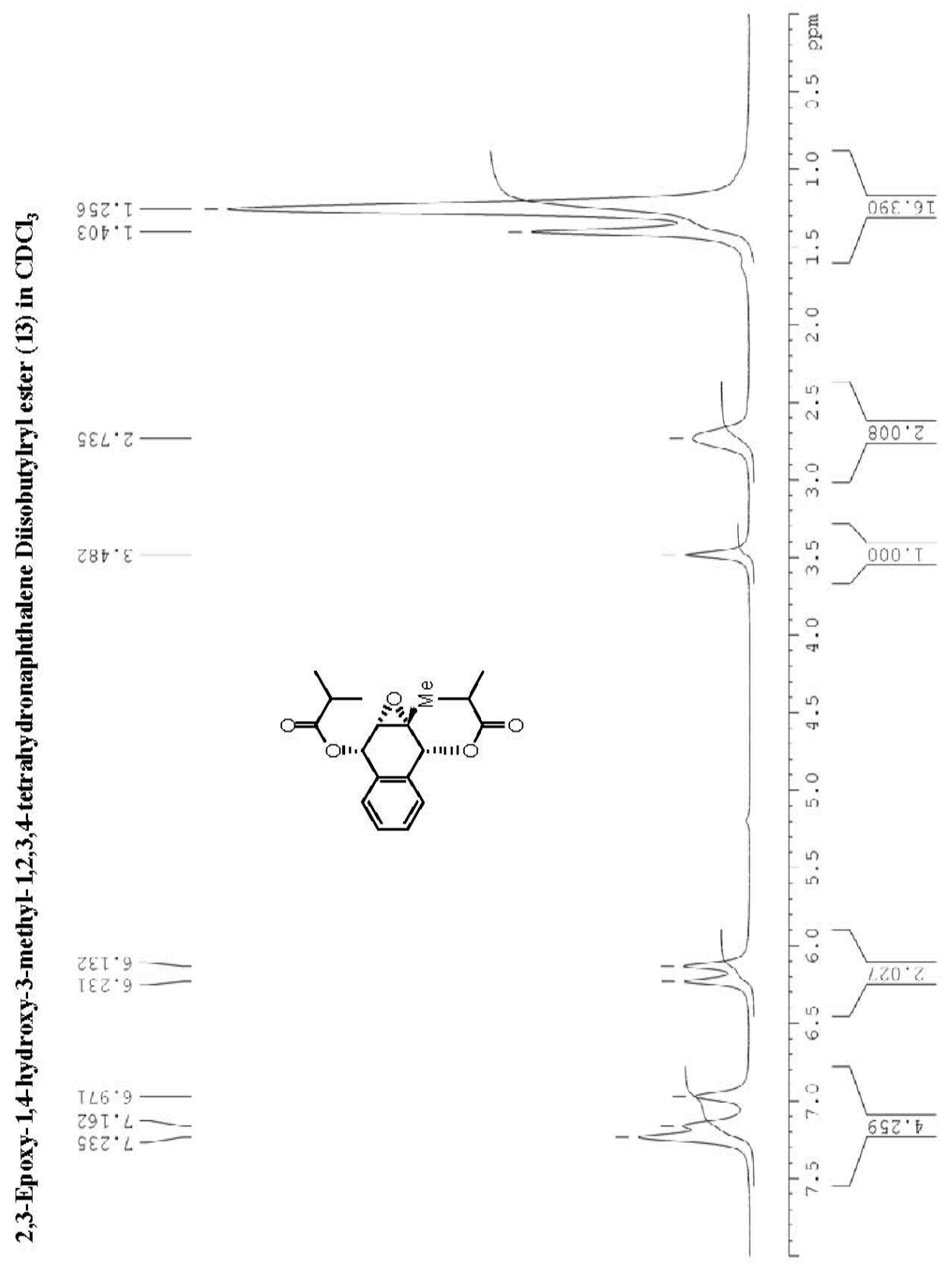



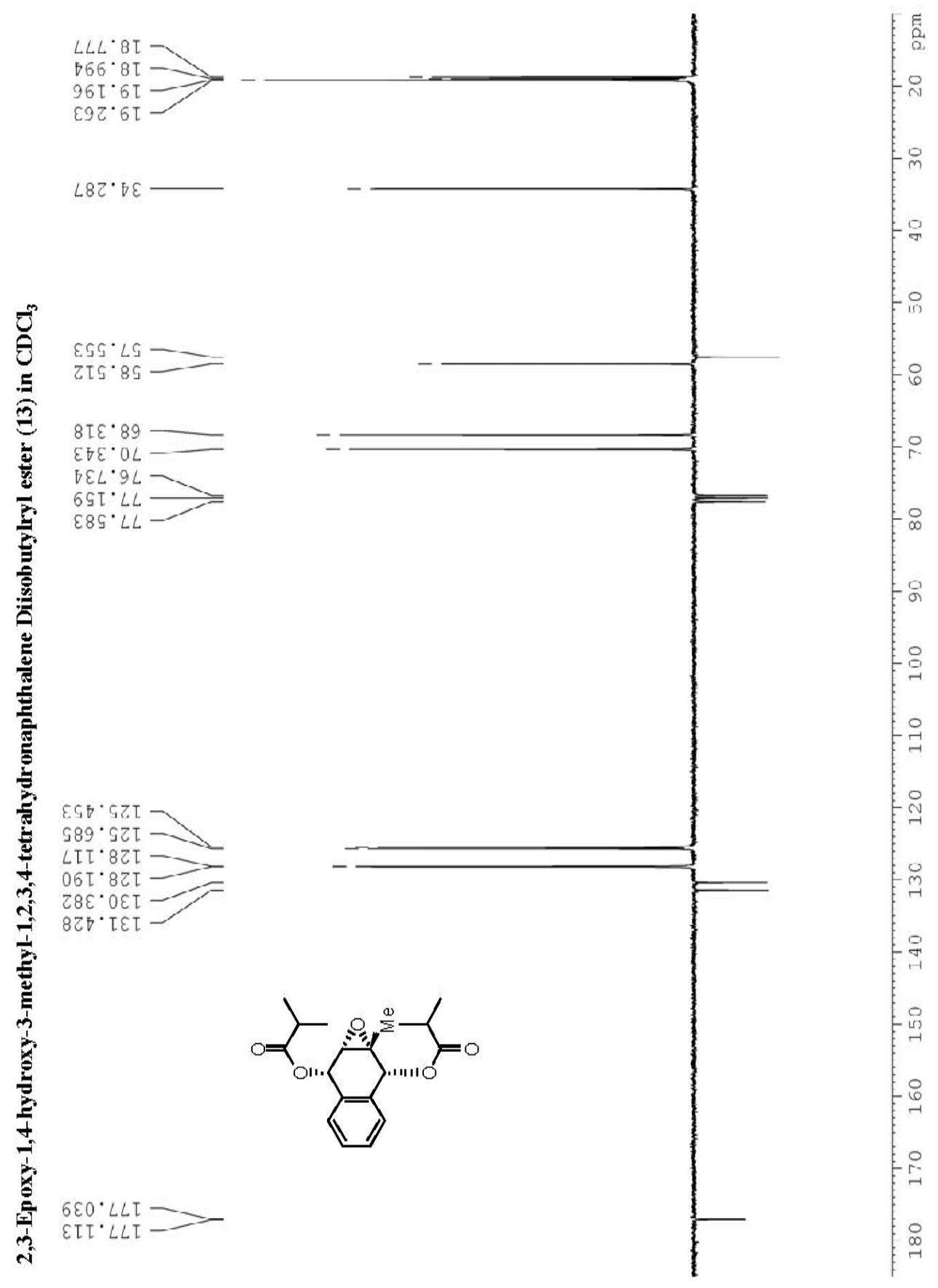


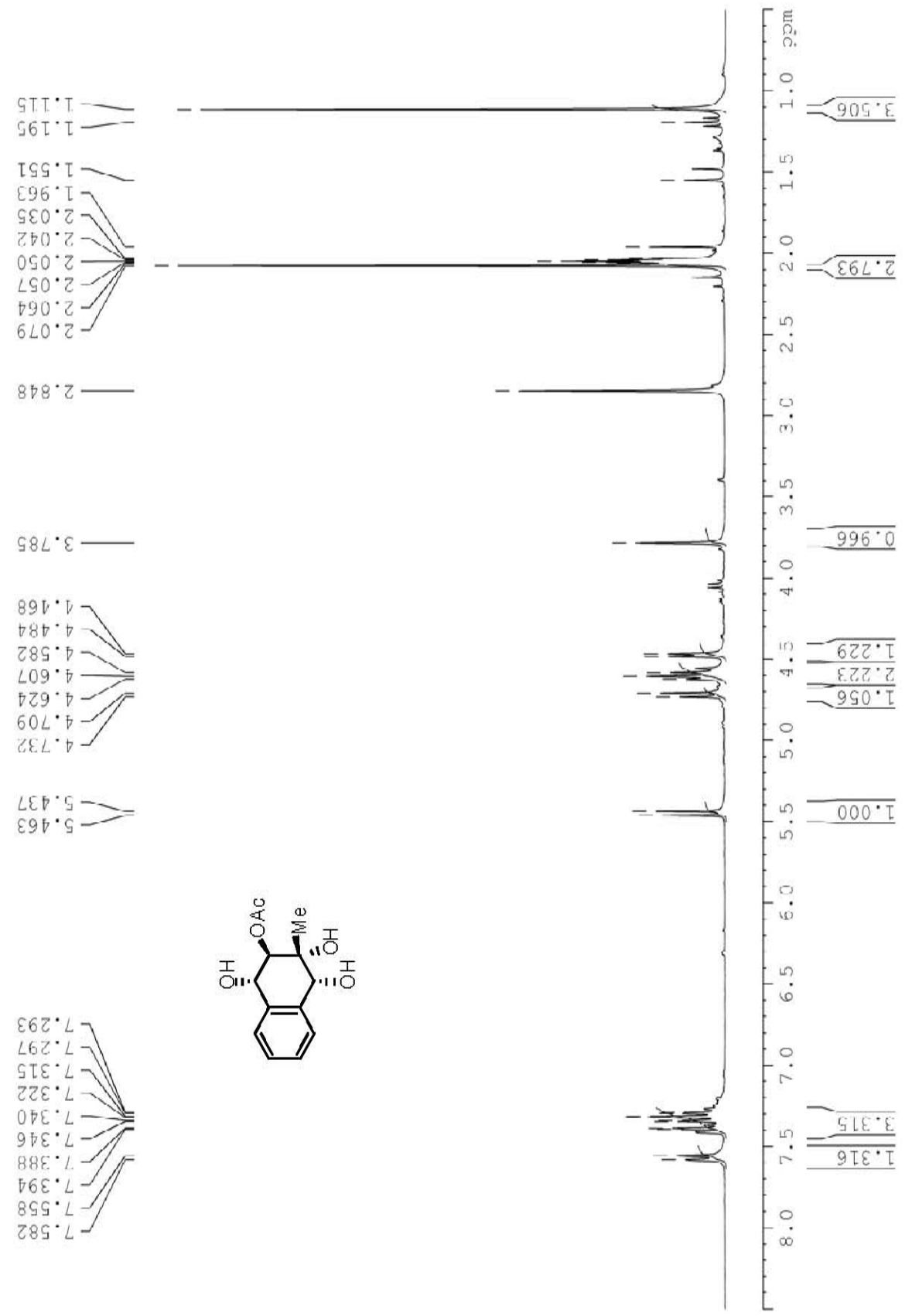




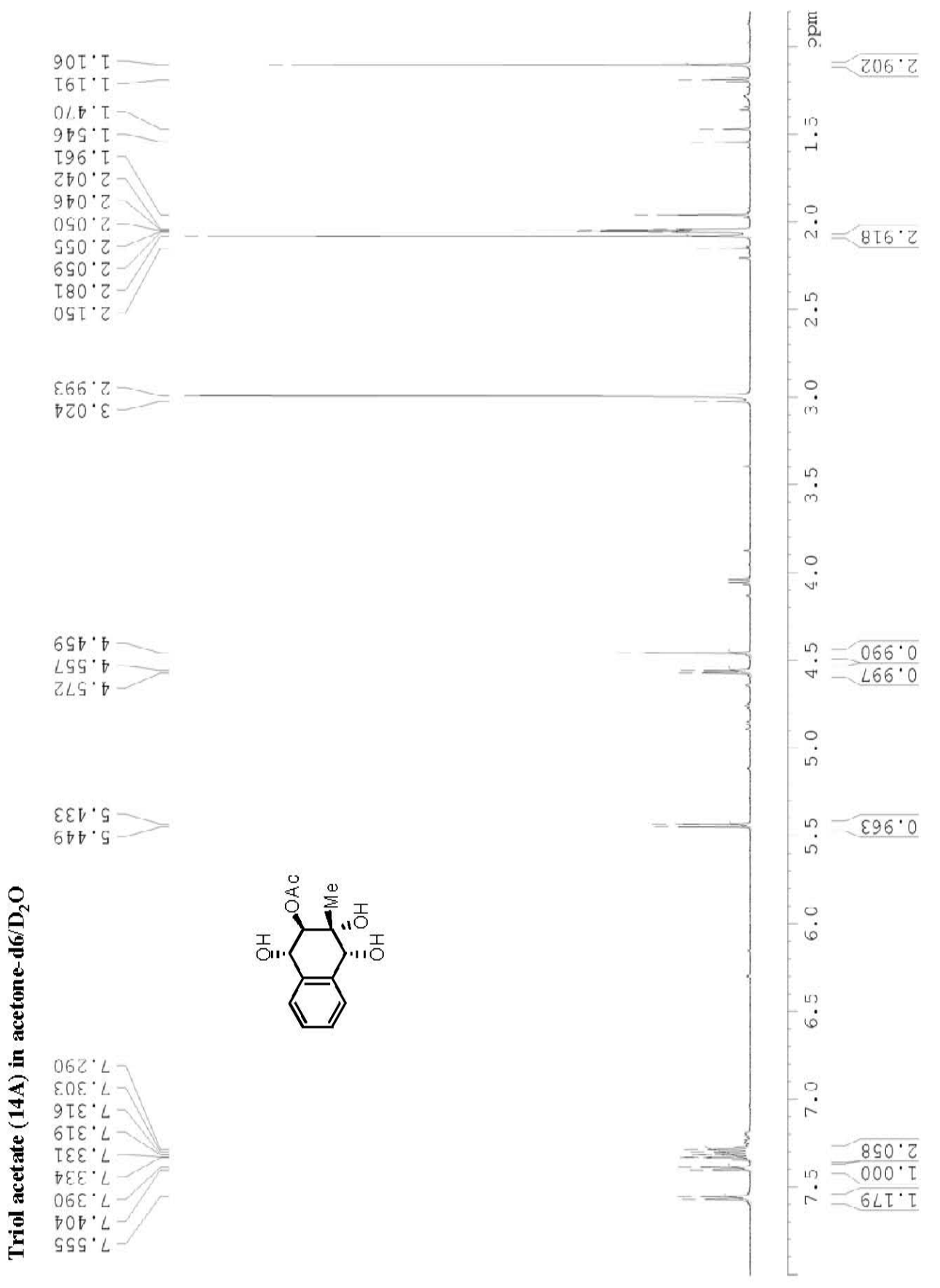




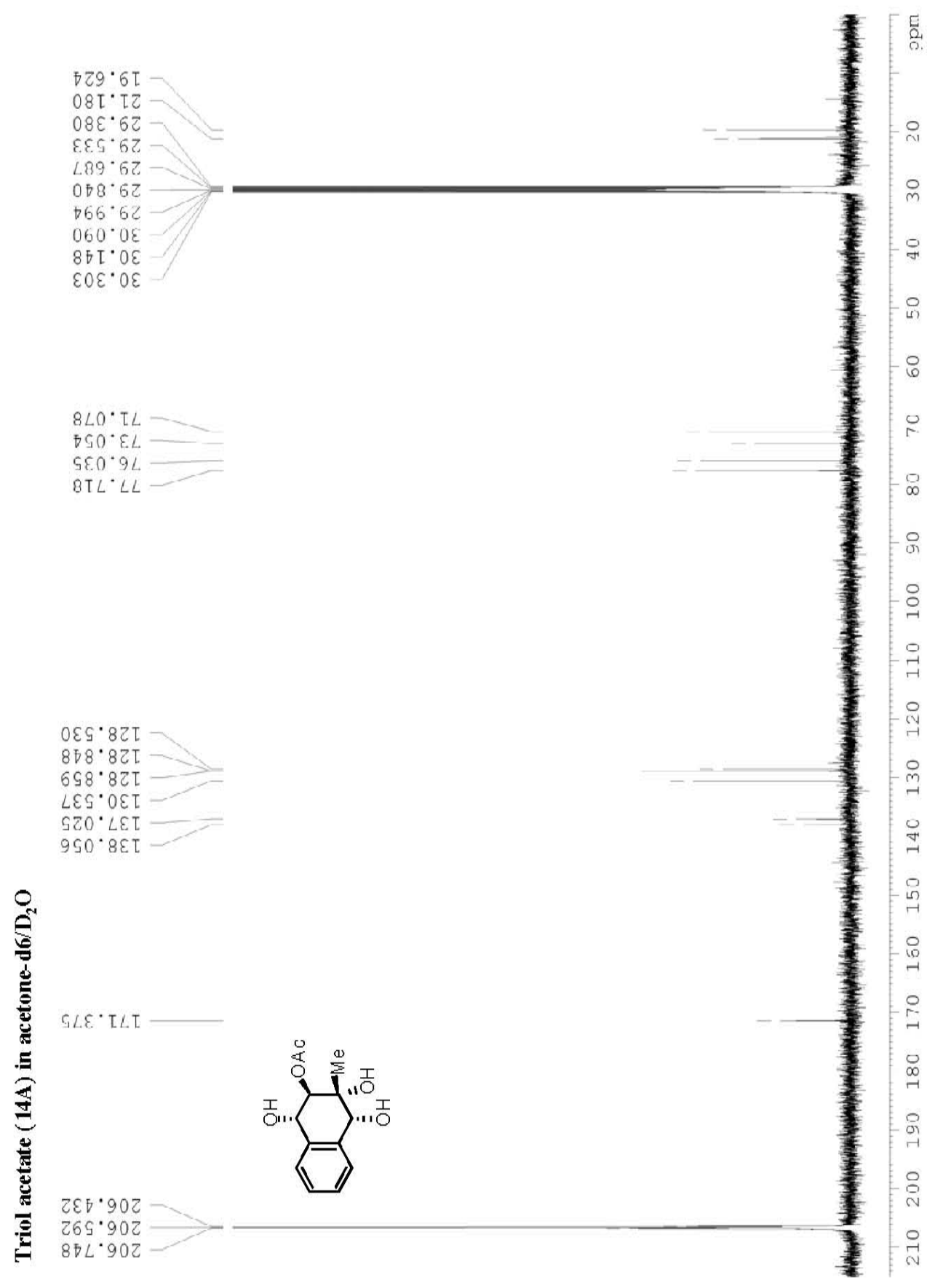




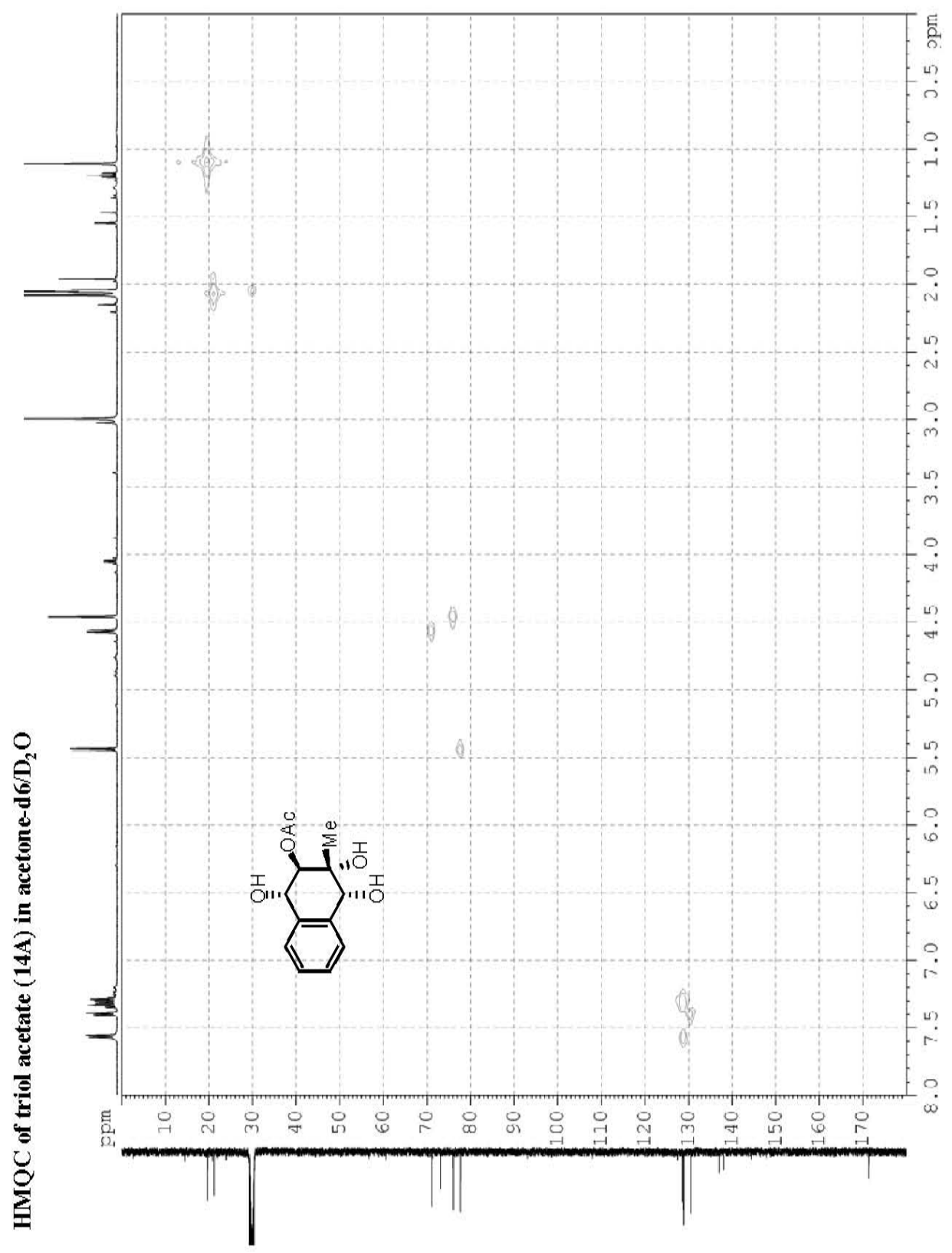




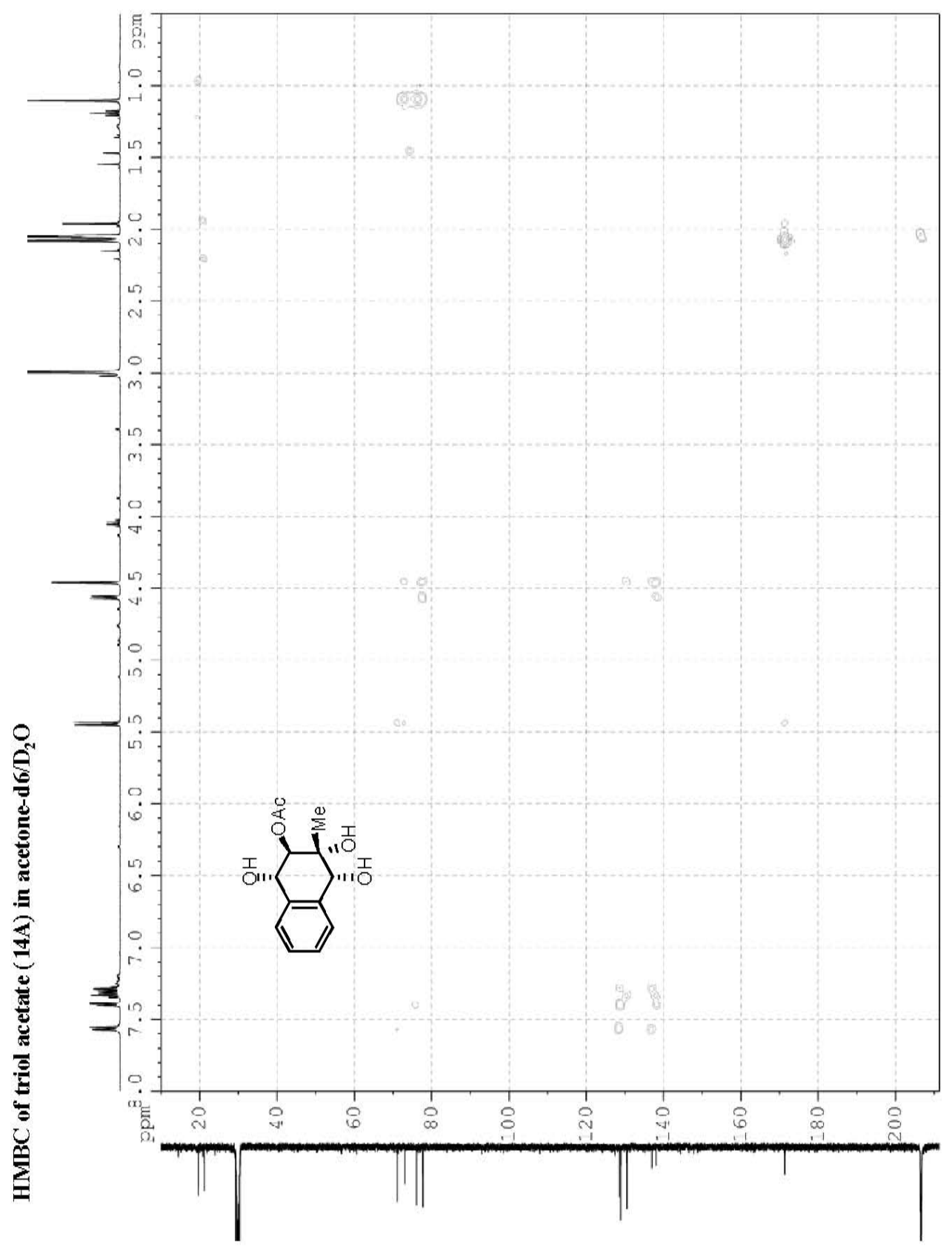




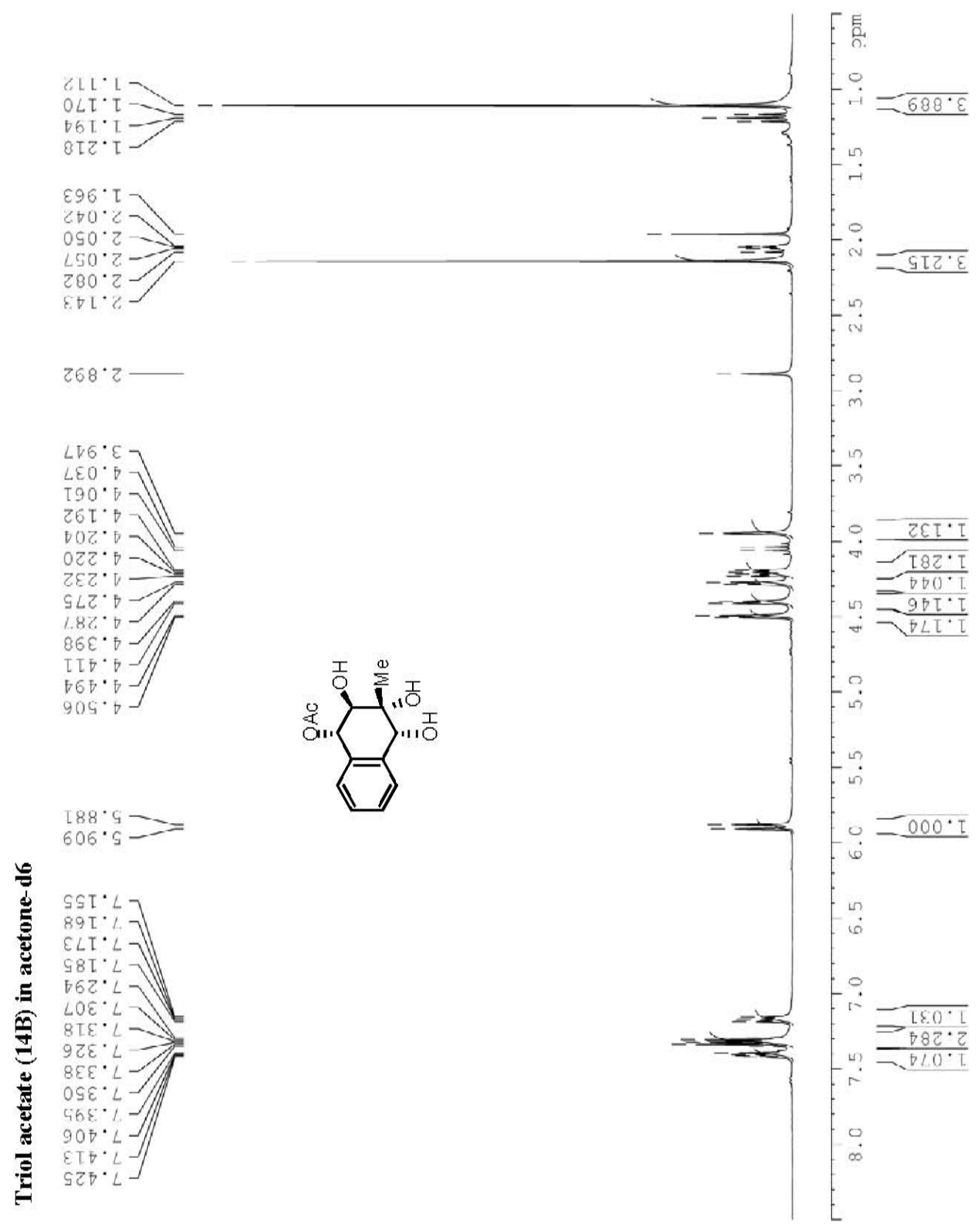




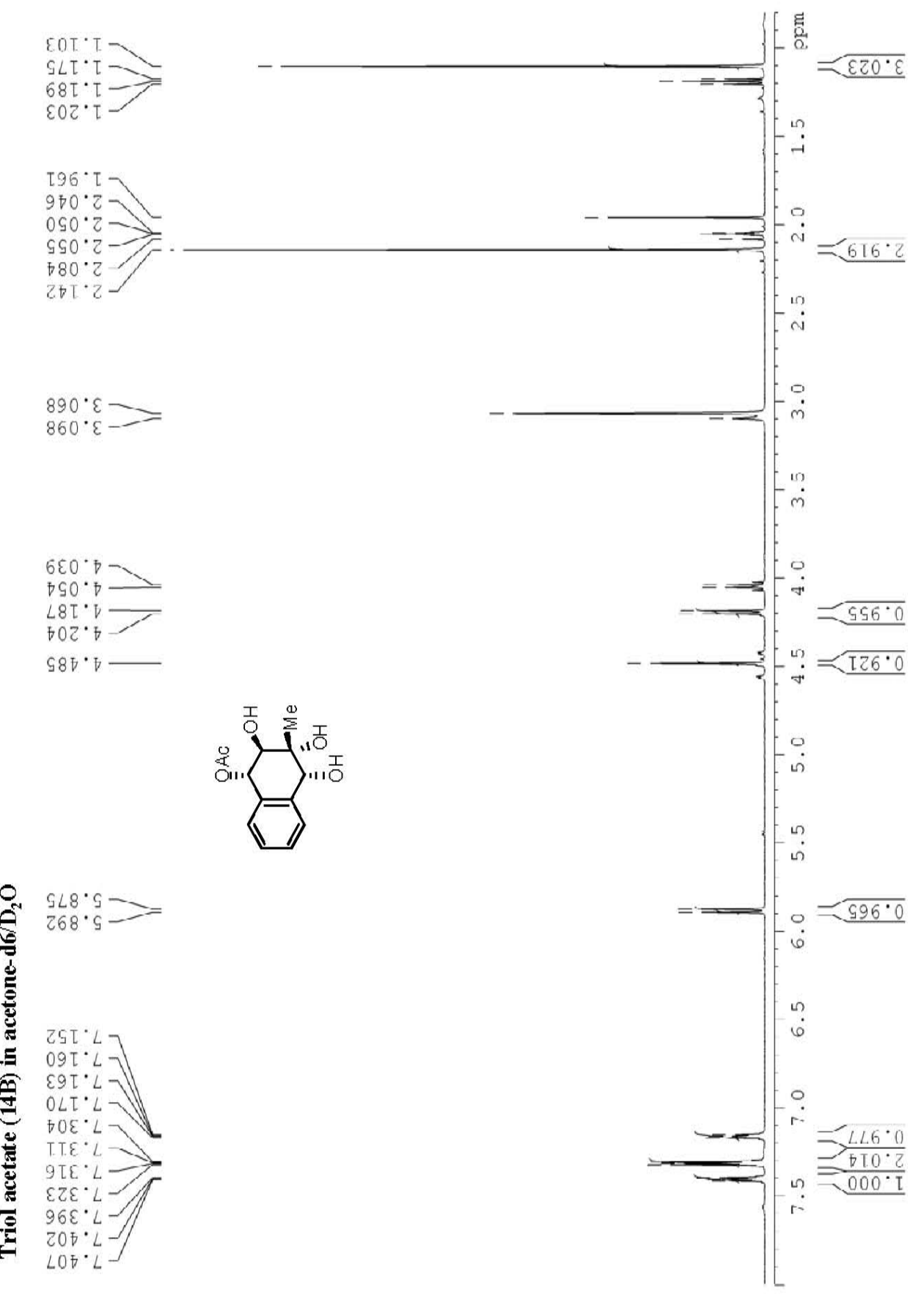




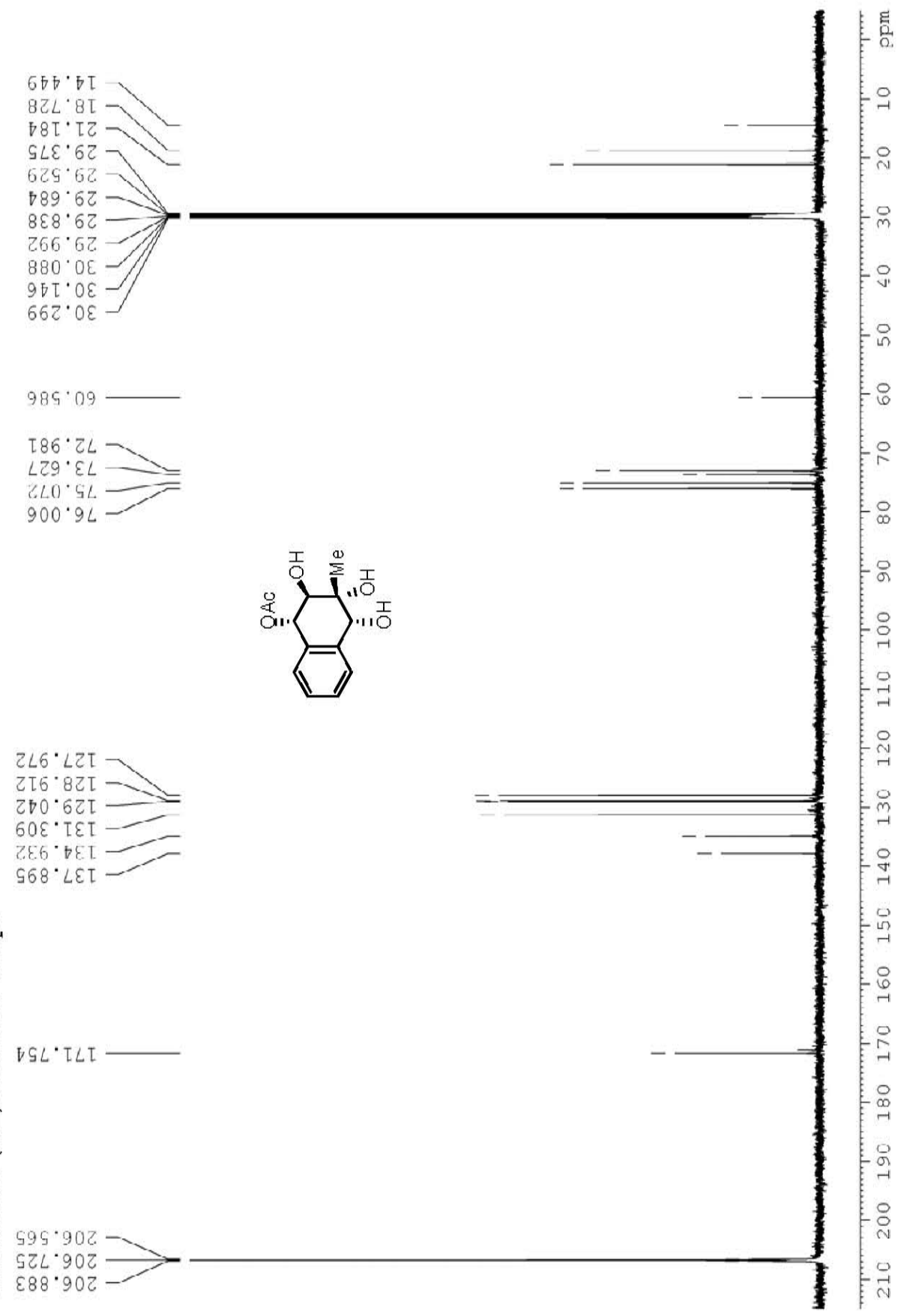




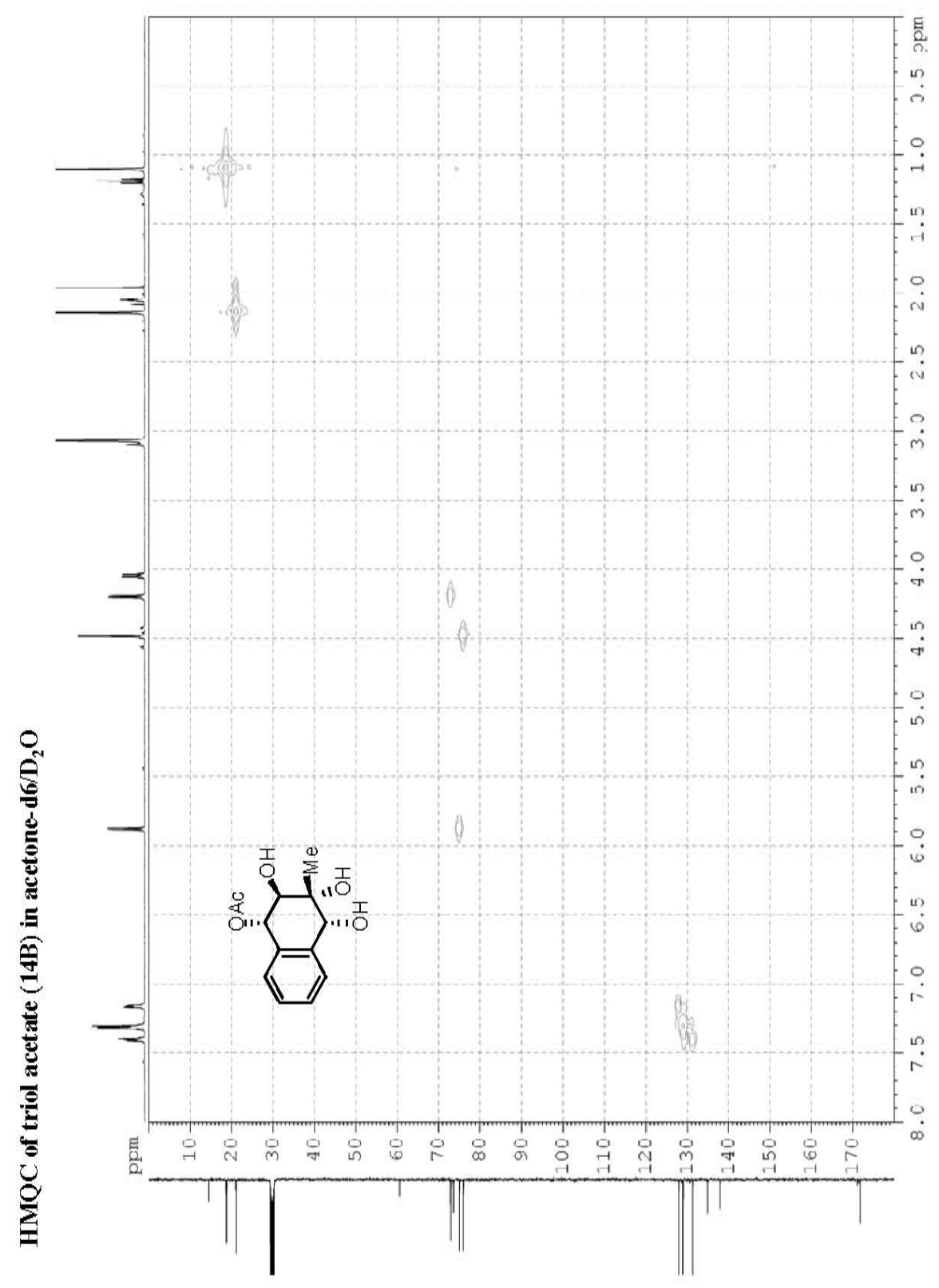




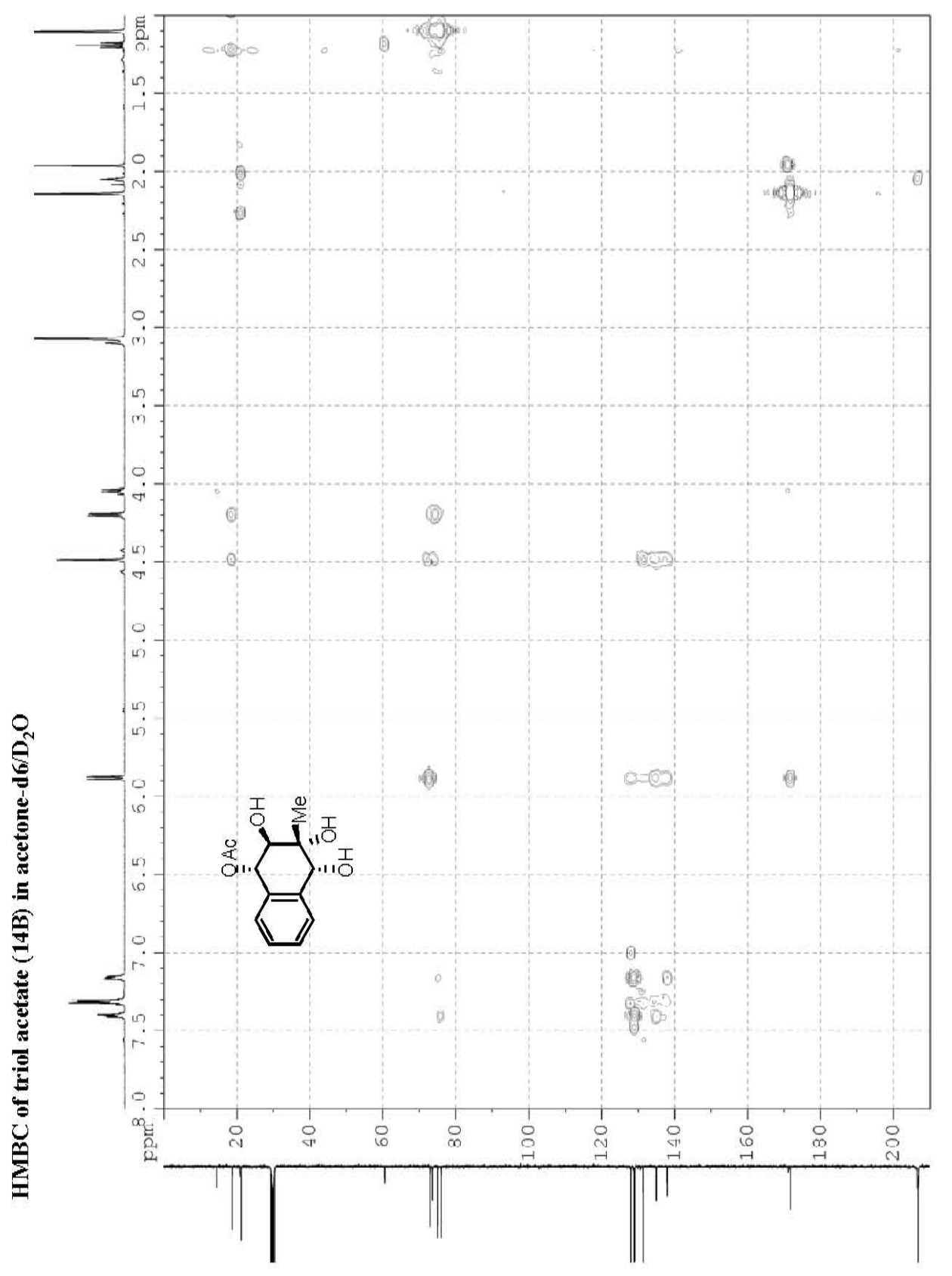




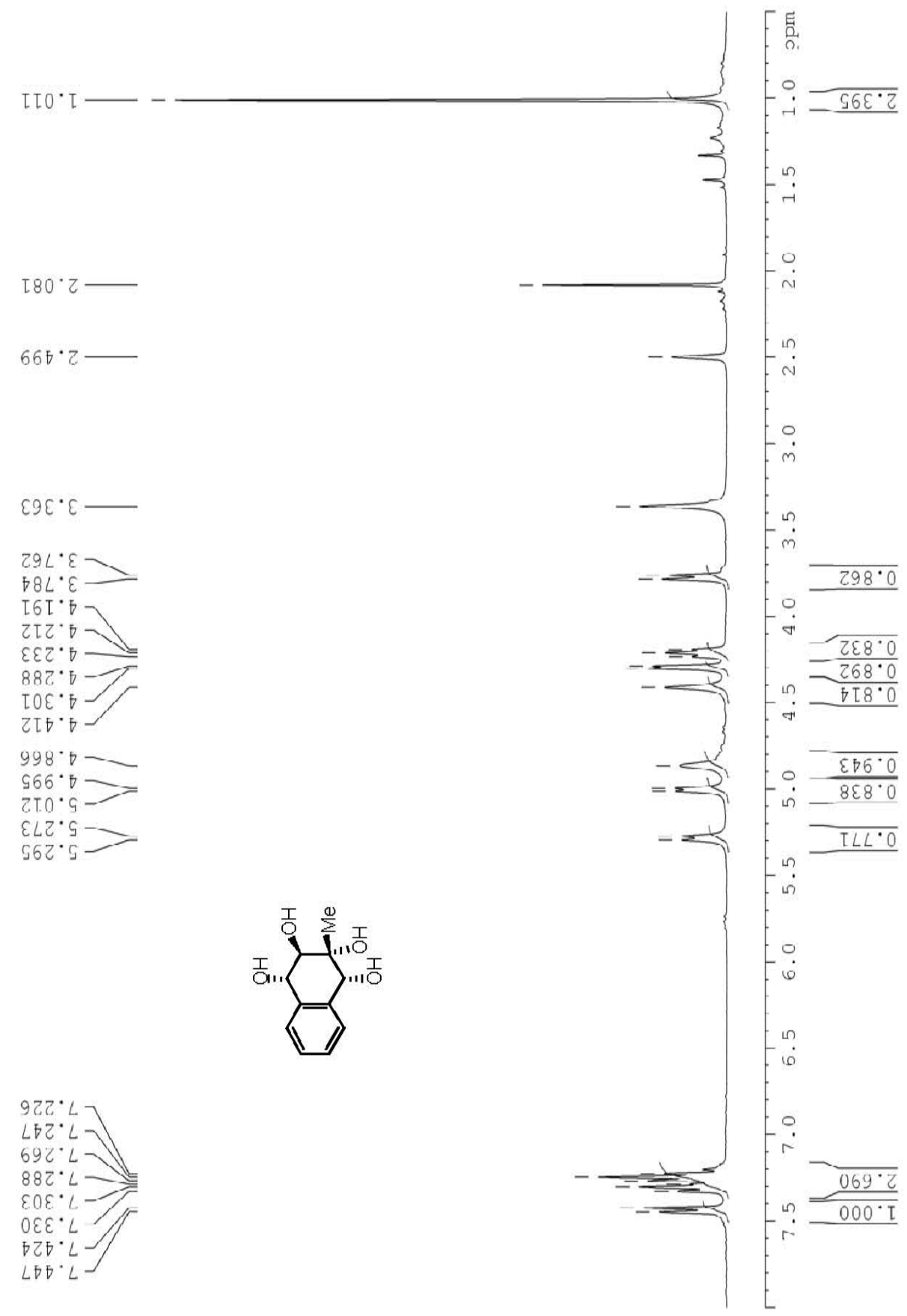




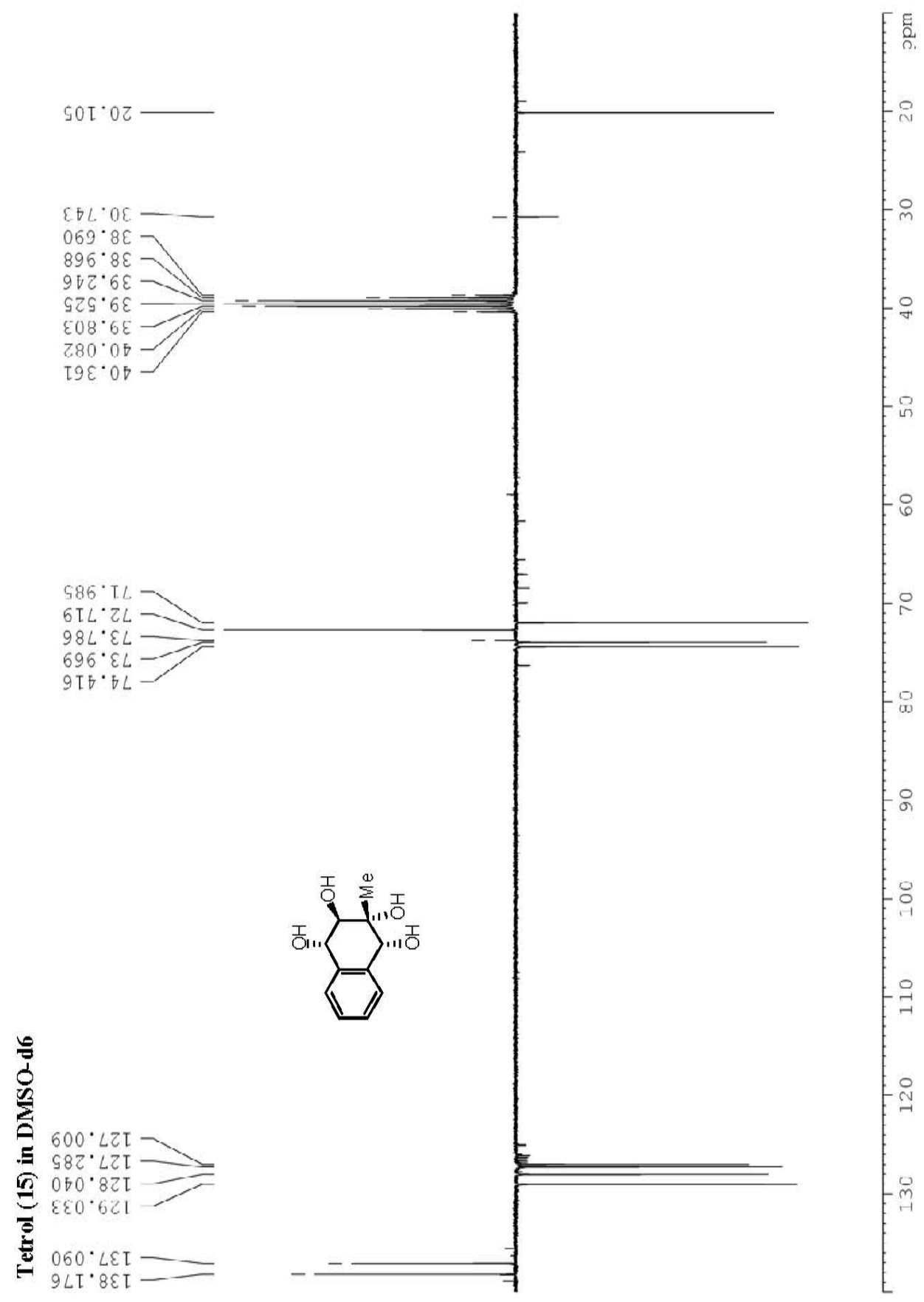




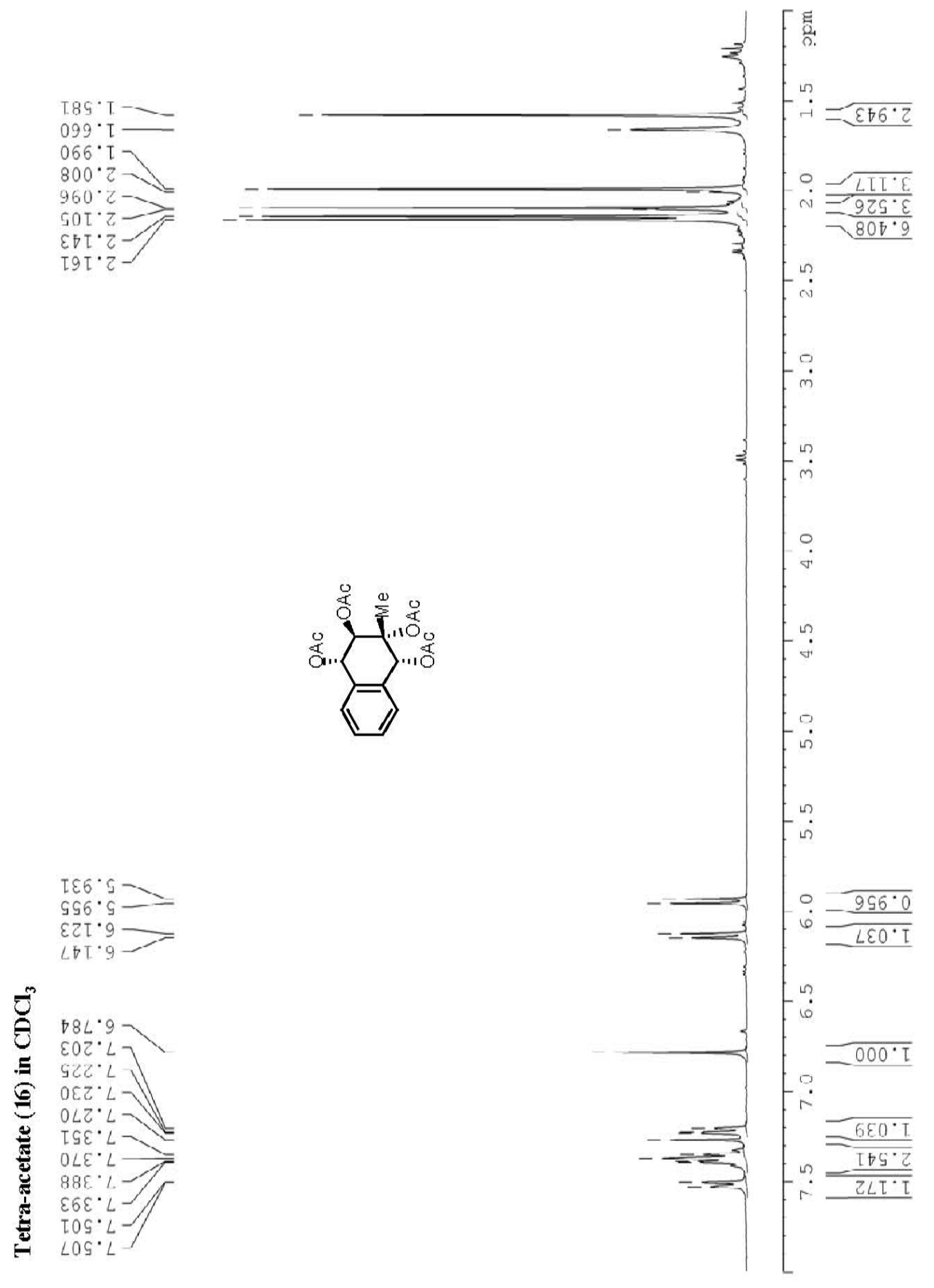



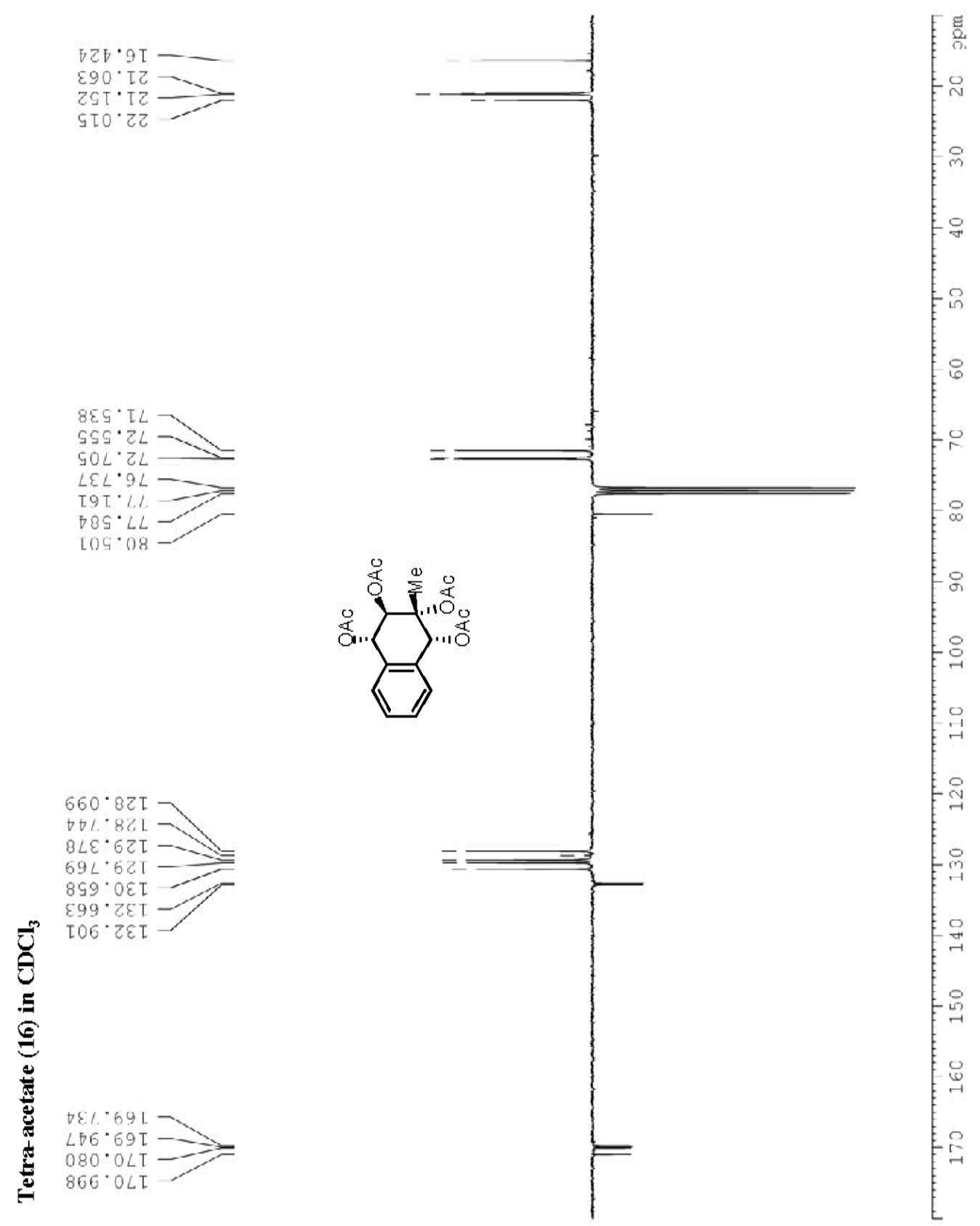


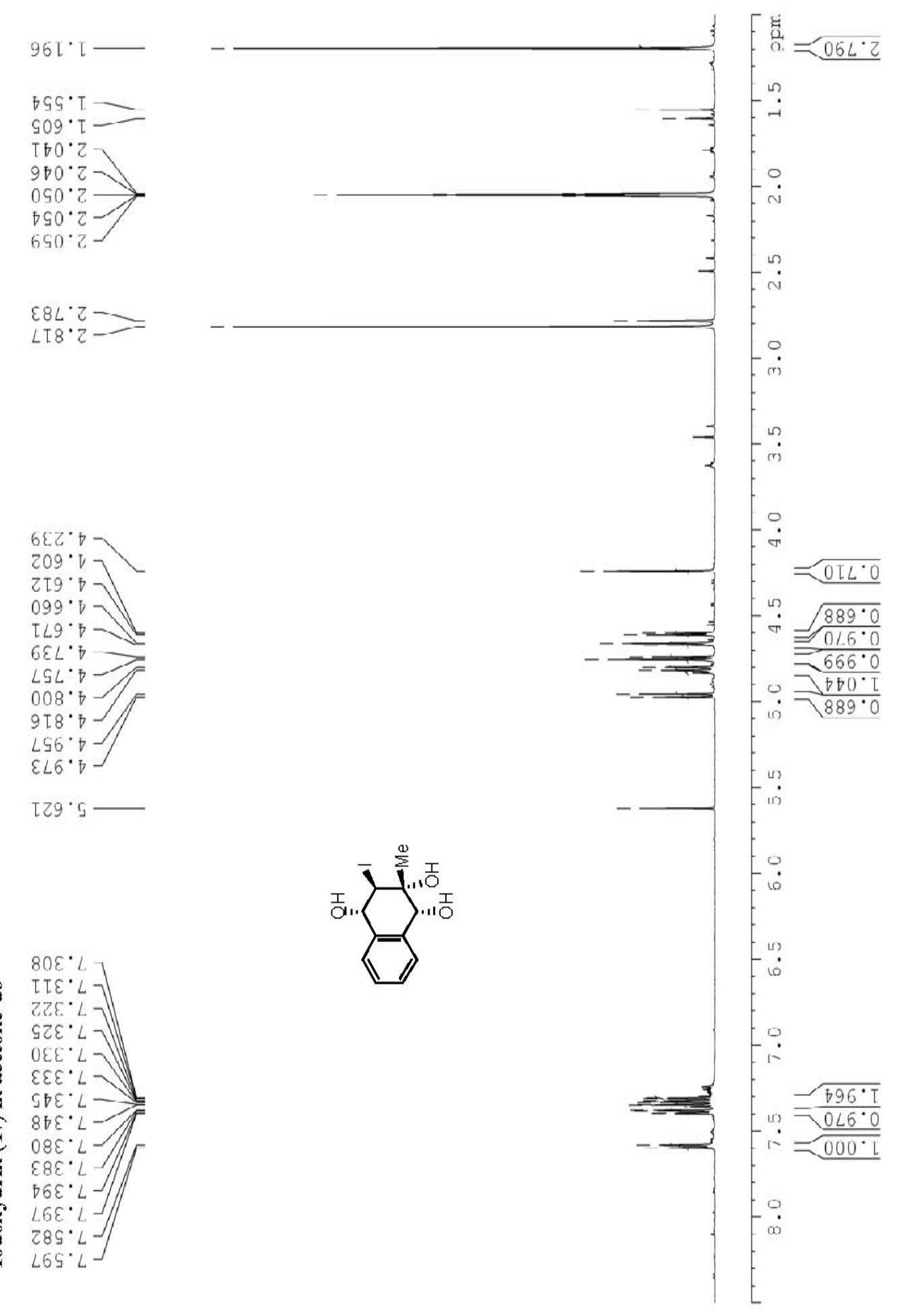




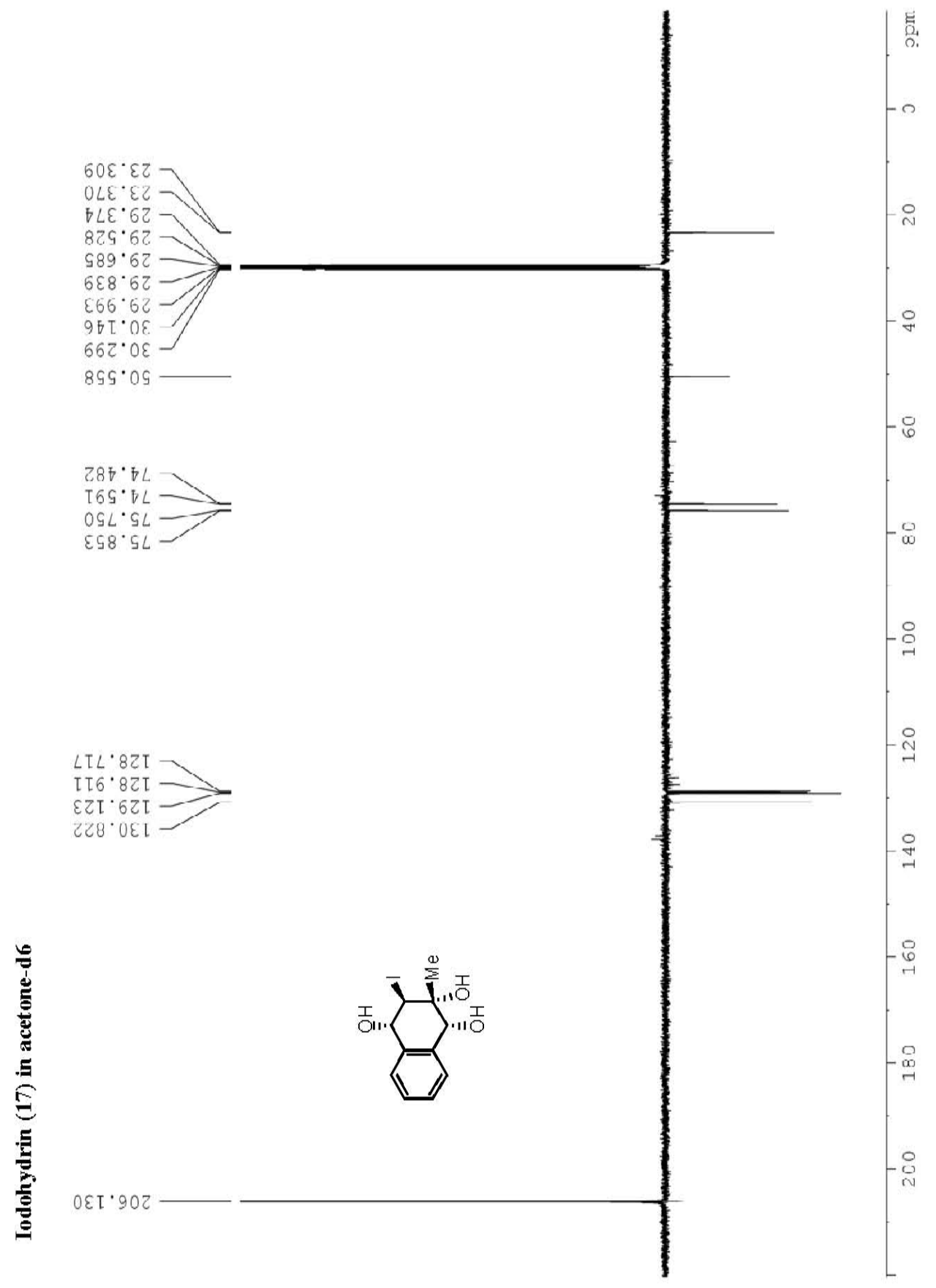




\section{II) NMR coupling constants of kinamycins and model compounds}

Table 1. Literature reported NMR coupling constants of some natural kinamycins in $\mathrm{CDCl}_{3}$

(1)


Table 2. Measured NMR coupling constants of some natural kinamycins and model compounds in various NMR solvents

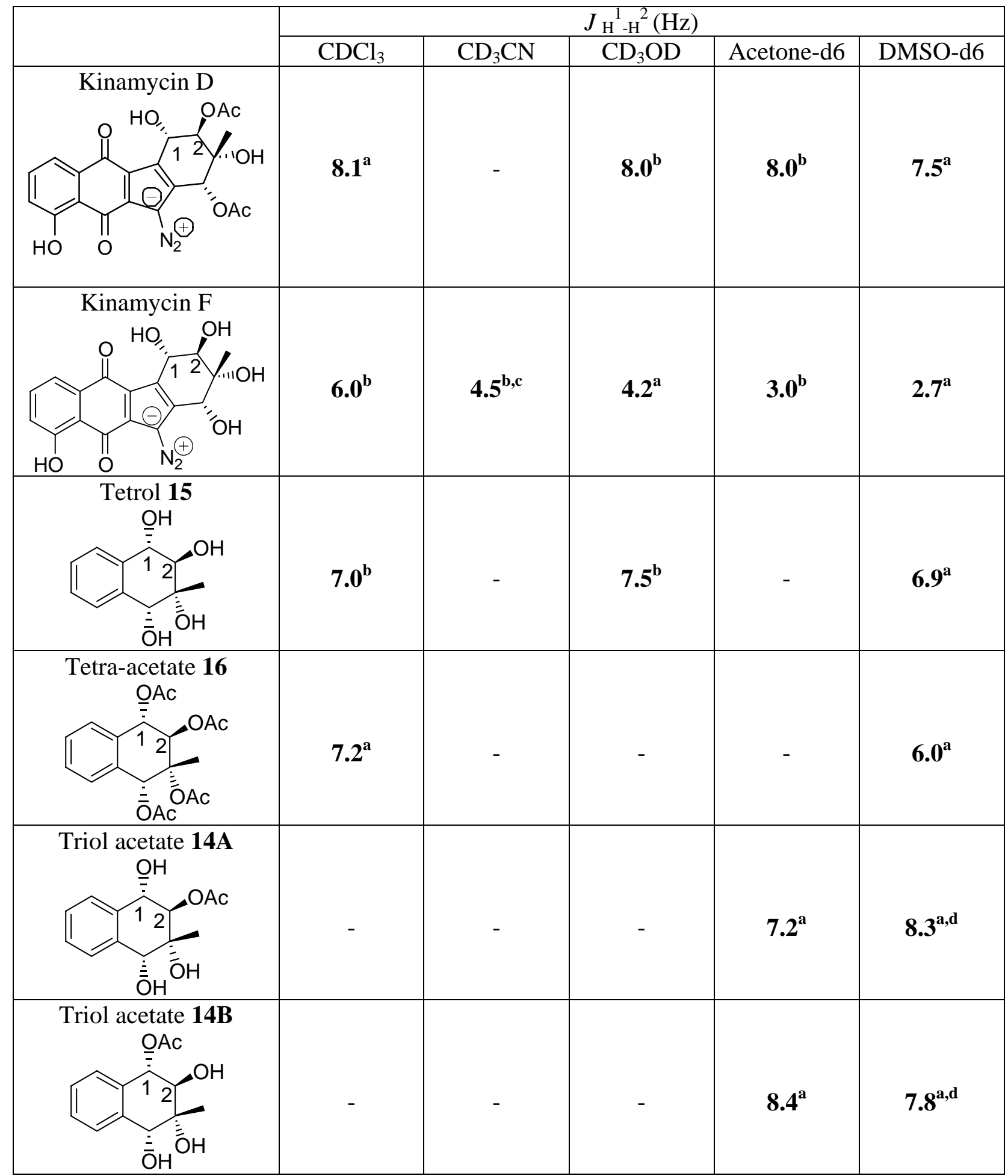

a. NMR spectra and coupling constants were measured on a $300 \mathrm{MHz}$ NMR spectrometer.

b. NMR spectra and coupling constants were measured on a $500 \mathrm{MHz}$ NMR spectrometer.

c. There was presence of $\mathrm{D}_{2} \mathrm{O}$ in the NMR sample.

d. The NMR sample was a mixture $(\sim 1: 1)$ of the two triol acetates $14 \mathrm{~A}$ and $14 \mathrm{~B}$. 


\section{III) $A b$ initio MO calculations of kinamycins}

All RHF $a b$ initio MO calculations were performed with Gaussian03 using the 6-31G basis set. ${ }^{8}$ PCM (Polarizable Continuum Model) is used for $a b$ initio MO calculations in solvent systems.

Table 3. $a b$ initio MO calculations of kinamycin $\mathrm{E}$ and kinamycin $\mathrm{F}$ in gas phase

\begin{tabular}{|c|c|c|c|}
\hline & \multicolumn{3}{|c|}{$\mathrm{E}(\mathrm{RHF})^{\mathrm{a}}$ (a.u. $^{\mathrm{b}}$} \\
\hline & Conformation A & Conformation B & $\Delta \mathrm{E}$ (a.u.) \\
\hline Kinamycin E & -1473.433862 & $\begin{array}{c}\text {-1473.441514 } \\
\text { conformation B is more } \\
\text { stable. }\end{array}$ & $\begin{array}{c}-0.007652 \\
(-4.8 \\
\mathrm{kcal} / \mathrm{mol})\end{array}$ \\
\hline Kinamycin $\mathrm{F}$ & Conformation A is more & -1321.773242 & $\begin{array}{c}0.000629 \\
(0.4 \\
\mathrm{kcal} / \mathrm{mol})\end{array}$ \\
\hline
\end{tabular}

a. The E(RHF) (restricted Hartree-Fork energy) has been corrected with ZPE (zero-point energy).

b. 1 a.u. $=627.5095 \mathrm{kcal} / \mathrm{mol}$ 
Table 4. ab initio MO calculations of kinamycin F in various solvent systems (PCM)

\begin{tabular}{|c|c|c|c|}
\hline & \multicolumn{2}{|c|}{$\mathrm{E}(\mathrm{RHF})(\text { a.u. })^{\mathrm{a}}$} & \\
\hline & Conformation A & Conformation B & $\Delta \mathrm{E}$ (RHF) (a.u.) \\
\hline \multirow{3}{*}{ Gas phase } & & & 0.000629 \\
\hline & -1321.773871 & -1321.773242 & $(0.4 \mathrm{kcal} / \mathrm{mol})$ \\
\hline & \multicolumn{2}{|c|}{$\Delta$ Gsolvation $(\mathrm{kcal} / \mathrm{mol})$} & \\
\hline Solvent & Conformation A & Conformation B & $\begin{array}{c}\Delta \Delta \text { Gsolvation }^{\mathrm{b}} \\
(\mathrm{kcal} / \mathrm{mol})\end{array}$ \\
\hline $\mathrm{CHCl}_{3}$ & -13.53 & -10.13 & 3.4 \\
\hline Acetone & -25.9 & -20.62 & 5.3 \\
\hline DMSO & -30.62 & -18.26 & 12.4 \\
\hline
\end{tabular}

a. 1 a.u. $=627.5095 \mathrm{kcal} / \mathrm{mol}$

b. Values are rounded to one decimal point. 


\section{IV) References}

1. Fieser, L. F.; Campbell, W. P.; Fry, E. M.; Gates, M. D. Jr. J. Am. Chem. Soc. 1939, 61, 32163223.

2. Sample was recrystallized from benzene starting with a ( 1:1) mixture of the two triol acetates 13A and 13B, and 13A is the only species that crystallized under such conditions.

3. Omura, S.; Nakagawa, A.; Yamada, H.; Hata, T.; Furusaki, A.; Watanabe, T.; Chem. Pharm. Bull. 1973, 21, 931-940.

4. Nicolaou, K. C.; Li, H.; Nold, A. L.; Pappo, D.; Lenzen, A.; J. Am. Chem. Soc. 2007, 129, 10356-10357.

5. Seaton, P. J.; Gould, S. J.; J. Antibiotics 1989, 42, 189-197.

6. Young, J.-J.; Ho, S.-N.; Ju, W.-M.; Chang, L.-R.; J. Antibiotics 1994, 47, 681-687.

7. Isshiki, K.; Sawa, T.; Naganawa, H.; Matsuda, N.; Hattori, S.; Hamada, M.; Takeuchi, T.;

Oosono, M.; Ishizuka, M.; Yang, Z.; Zhu, B.; Yao, W.; J. Antibiotics 1989, 42, 467-469.

8. Gaussian 03, Revision B.04, M. J. Frisch, G. W. Trucks, H. B. Schlegel, G. E. Scuseria, M. A. Robb, J. R. Cheeseman, J. A. Montgomery, Jr., T. Vreven, K. N. Kudin, J. C. Burant, J. M. Millam, S. S. Iyengar, J. Tomasi, V. Barone, B. Mennucci, M. Cossi, G. Scalmani, N. Rega, G. A. Petersson, H. Nakatsuji, M. Hada, M. Ehara, K. Toyota, R. Fukuda, J. Hasegawa, M. Ishida, T. Nakajima, Y. Honda, O. Kitao, H. Nakai, M. Klene, X. Li, J. E. Knox, H. P. Hratchian, J. B. Cross, C. Adamo, J. Jaramillo, R. Gomperts, R. E. Stratmann, O. Yazyev, A. J. Austin, R. Cammi, C. Pomelli, J. W. Ochterski, P. Y. Ayala, K. Morokuma, G. A. Voth, P. Salvador, J. J. Dannenberg, V. G. Zakrzewski, S. Dapprich, A. D. Daniels, M. C. Strain, O. Farkas, D. K. Malick, A. D. Rabuck, K. Raghavachari, J. B. Foresman, J. V. Ortiz, Q. Cui, A. G. Baboul, S. Clifford, J. Cioslowski, B. B. Stefanov, G. Liu, A. Liashenko, P. Piskorz, I. Komaromi, R. L. Martin, D. J. Fox, T. Keith, M. A. Al-Laham, C. Y. Peng, A. Nanayakkara, M. Challacombe, P. M. W. Gill, B. Johnson, W. Chen, M. W. Wong, C. Gonzalez, and J. A. Pople, Gaussian, Inc., Pittsburgh PA, 2003. 